\title{
Marine Fungi: Biotechnological Perspectives from Deep-Hypersaline Anoxic Basins
}

\author{
Giulio Barone ${ }^{1,+}\left(\mathbb{D}\right.$, Stefano Varrella ${ }^{2,+} \mathbb{C}$, Michael Tangherlini ${ }^{1} \mathbb{C}$, Eugenio Rastelli ${ }^{1}$, \\ Antonio Dell'Anno ${ }^{3}$, Roberto Danovaro ${ }^{1,3}$ and Cinzia Corinaldesi ${ }^{2, *}$ \\ 1 Stazione Zoologica Anton Dohrn, Villa Comunale, 80121 Naples, Italy \\ 2 Department of Materials, Environmental Sciences and Urban Planning, Polytechnic University of Marche, \\ 60131 Ancona, Italy \\ 3 Department of Life and Environmental Sciences, Polytechnic University of Marche, 60131 Ancona, Italy \\ * Correspondence: c.corinaldesi@univpm.it \\ + These authors contributed equally.
}

Received: 13 May 2019; Accepted: 12 July 2019; Published: 16 July 2019

\begin{abstract}
Deep-sea hypersaline anoxic basins (DHABs) are one of the most hostile environments on Earth. Even though DHABs have hypersaline conditions, anoxia and high hydrostatic pressure, they host incredible microbial biodiversity. Among eukaryotes inhabiting these systems, recent studies demonstrated that fungi are a quantitatively relevant component. Here, fungi can benefit from the accumulation of large amounts of organic material. Marine fungi are also known to produce bioactive molecules. In particular, halophilic and halotolerant fungi are a reservoir of enzymes and secondary metabolites with valuable applications in industrial, pharmaceutical, and environmental biotechnology. Here we report that among the fungal taxa identified from the Mediterranean and Red Sea DHABs, halotolerant halophilic species belonging to the genera Aspergillus and Penicillium can be used or screened for enzymes and bioactive molecules. Fungi living in DHABs can extend our knowledge about the limits of life, and the discovery of new species and molecules from these environments can have high biotechnological potential.
\end{abstract}

Keywords: marine fungi; deep hypersaline anoxic basins; blue biotechnologies; deep sea

\section{Introduction}

Deep-sea ecosystems represent the last frontier of scientific research in marine ecosystems [1]. Compared to terrestrial and coastal ecosystems, the deep sea (beyond $200 \mathrm{~m}$ below sea level) hosts some of the most extreme habitats, characterised by complete darkness, wide temperature ranges from below $0{ }^{\circ} \mathrm{C}$ to $450{ }^{\circ} \mathrm{C}$ or more, and high hydrostatic pressure of average $400 \mathrm{~atm}[2,3]$. The deep sea also includes the deep-sea hypersaline anoxic basins (DHABs), which are depressions of the seafloor found at more than $2 \mathrm{~km}$ below the sea level. Since DHABs were first discovered in the Red Sea [4,5], more than 36 hypersaline basins have been observed in regions all over of the world (Figure 1), from the Mediterranean Sea to the Gulf of Mexico and also in the Black Sea [6]. Although DHAB geological features can change considerably from case to case, most DHABs originated from the re-dissolution of evaporitic deposits buried under layers of sediments and exposed to seawater because of tectonic activity [7]. Therefore, chemical and physical characteristics are specific to each DHAB ([6] and references therein). Overall, salinity can vary from 240 to 500 PSU $[7,8]$ with variable concentrations of halite ( $\mathrm{NaCl}$-mineral) $[9,10]$, kieserite $\left(\mathrm{MgSO}_{4}\right.$-mineral) [9-11], sulphate $[9,10]$ and other minerals, as well as toxic compounds, such as hydrogen sulphide, ammonium, and manganese [6]. The dissolution of the anciently buried evaporites creates a thick layer of brines, which are separated by a halocline from the overlying oxygenated deep-seawater column [9]. Thus, microbial degradation of organic 
matter within the basin eventually consumes the oxygen available in the water, and since this cannot mix with the overlying oxygenated water, the basin becomes ultimately anoxic. Anoxia and sulfidic conditions combined with the high salinity and hydrostatic pressure and the absence of light, make these deep, hypersaline, anoxic basins some of the most hostile environments on our planet.

Although life has been thought to be absent in such conditions, DHABs provided relevant insights into the extent of life for all three domains, including the possible presence of living metazoans [8,10,12-20]. Other studies on molecular diversity, metabolic activities and microscopy analyses have revealed diverse and abundant prokaryotic assemblages [18,21-25]. At the same time, investigations on eukaryotic life obtained by ribosomal DNA analyses and microscopic images showed the presence of unexpected micro-eukaryotic communities thriving in DHABs where fungi accounted for a high number of reads or operational taxonomic units (OTUs)/phylotypes to the entire assemblage [12,26,27].

Fungi are essential decomposers of organic matter and play a key role in carbon cycling and food web dynamics in terrestrial and marine ecosystems, also including mutualistic, parasitic and pathogenic taxa [28,29]. In particular, saprotrophic fungi are known to produce a vast array of organic compounds and enzymes able to decompose even the most recalcitrant fraction of natural and human-made organic materials [30]. In the Tethis basin, the relative abundance of the rRNA reads of fungi was high, especially in the lower halocline where the conditions of salinity and oxygen are more challenging [31,32]. Since organic material accumulates at the halocline, fungi have been suggested to be active remineralisers in such extreme conditions [31,32].

Fungi, among marine organisms, produce a large and diverse array of bioactive compounds exploitable for several biotechnological purposes [33]. However, quantitative relevance, diversity, ecological role and adaptations of fungi to the extreme conditions of DHABs are still largely unexplored. Consequently, the bioactive compounds they produce remain still unexploited also. The present review provides an overview of the fungal ecology and diversity in DHAB systems highlighting their potential in producing enzymes and bioactive molecules for industrial, pharmaceutical and environmental applications.

\section{Fungi in DHABs}

Advances in "omics" analyses, including next-generation sequencing, genome mining, and bioinformatic tools revealed that fungi are an important eukaryotic group in several DHABs. Although the information is still limited, Ascomycota and Basidiomycota fungi were identified in many DHABs from the Mediterranean and Red Seas, mostly through high-throughput sequencing analyses (Table 1). For example, fungi were found in the upper and lower halocline of L'Atalante basin $[12,26]$ and in the Thetis basin [27]. In the brine pool adjacent to Thuwal cold seep as well as in the Discovery and L'Atalante basins, fungal reads contributed to 68 to $99 \%$ of the eukaryotic reads [26,34].
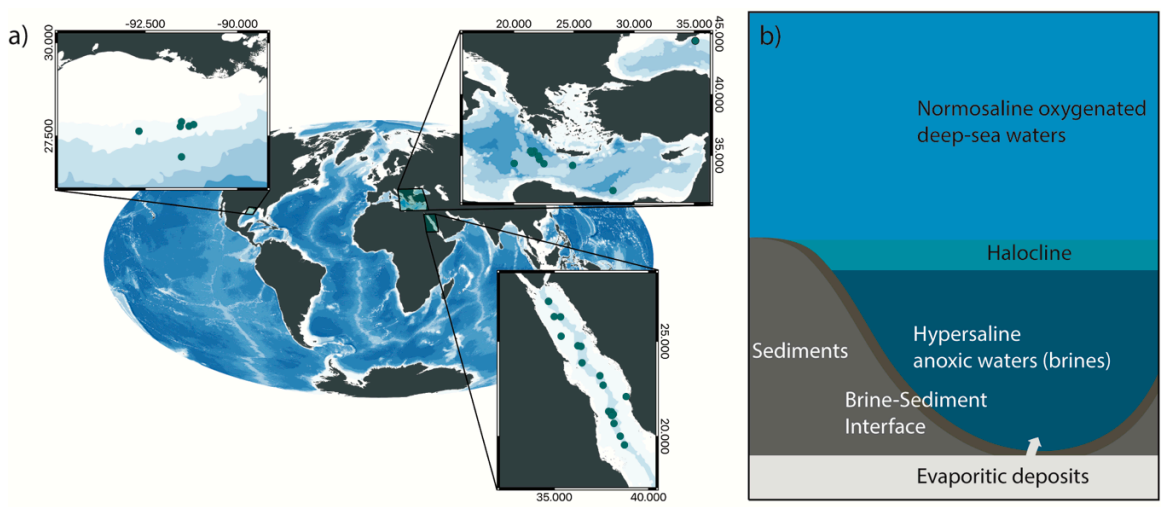

Figure 1. Locations of the DHABs identified in the Gulf of Mexico, Mediterranean Sea, Black Sea and the Red Sea (a) (for detailed elucidation on the environmental features and coordinates see [6]). Schematic vertical section of a generic DHAB showing the normo-saline oxygenated deep water, halocline and anoxic brines, brine-sediment interface and sediments $(\mathbf{b})$. 
Table 1. List of fungal taxa identified in deep-sea hypersaline anoxic basins. Taxa are expressed as Sub-Division (SD), Order (O), Class (C) and Family (F).

\begin{tabular}{|c|c|c|c|c|c|c|}
\hline Fungal Taxon/Closest Relative & DHAB & Site & Depth & Area & Coordinates & Reference \\
\hline Malasseziales $(\mathrm{O})$ & Bannock & Halocline & 3330 & Mediterranean & $34^{\circ} 17.488^{\prime} \mathrm{N} 20^{\circ} 00.692^{\prime} \mathrm{E}$ & [20] \\
\hline Malasseziomycetes (C), Microbotryomycetes (C) and Dothideomycetes (C) & Discovery & Upper halocline & 3582 & Mediterranean & $35^{\circ} 17.150^{\prime} \mathrm{N} 21^{\circ} 42.308^{\prime} \mathrm{E}$ & [26] \\
\hline Aspergillus and Penicillium & Discovery & Upper halocline & 3583 & Mediterranean & $35^{\circ} 17.150^{\prime} \mathrm{N} 21^{\circ} 42.308^{\prime} \mathrm{E}$ & [35] \\
\hline Aspergillus and Penicillium & Discovery & Lower halocline & 3586 & Mediterranean & $35^{\circ} 17.150^{\prime} \mathrm{N} 21^{\circ} 42.308^{\prime} \mathrm{E}$ & [35] \\
\hline $\begin{array}{c}\text { Aspergillus, Penicillium, Sordaria, Rhodothorula glutinis, R. mucillaginosa } \\
\text { Ustilaginomycetes (C) }\end{array}$ & L'Atalante & Upper halocline & 3499 & Mediterranean & $35^{\circ} 18.865^{\prime} \mathrm{N} 21^{\circ} 24.338^{\prime} \mathrm{E}$ & [12] \\
\hline Ustilaginomycetes (C) & L'Atalante & Lower halocline & 3501 & Mediterranean & $35^{\circ} 18.865^{\prime} \mathrm{N} 21^{\circ} 24.338^{\prime} \mathrm{E}$ & [12] \\
\hline Malasseziomycetes (C), Microbotryomycetes (C) and Dothideomycetes (C) & L'Atalante & Upper halocline & 3430 & Mediterranean & $35^{\circ} 18.865^{\prime} \mathrm{N} 21^{\circ} 24.338^{\prime} \mathrm{E}$ & [26] \\
\hline Malasseziomycetes (C), Microbotryomycetes (C) and Dothideomycetes (C) & L'Atalante & Lower halocline & 3430 & Mediterranean & $35^{\circ} 18.865^{\prime} \mathrm{N} 21^{\circ} 24.338^{\prime} \mathrm{E}$ & [26] \\
\hline Aspergillus and several Ascomycota and Basidiomycota strains & L'Atalante & Lower halocline & 3501 & Mediterranean & $35^{\circ} 18.865^{\prime} \mathrm{N} 21^{\circ} 24.338^{\prime} \mathrm{E}$ & [35] \\
\hline Fungi & Thetis & Lower halocline & 3258 & Mediterranean & $34^{\circ} 40.158^{\prime} \mathrm{N} 22^{\circ} 08.703^{\prime} \mathrm{E}$ & [31] \\
\hline Rhodotorula mucillaginosa, Malasseziales (O) and Atheliaceae (F) & Thetis & Halocline & 3258 & Mediterranean & $34^{\circ} 40.189^{\prime} \mathrm{N} 22^{\circ} 8.728^{\prime} \mathrm{E}$ & [27] \\
\hline $\begin{array}{l}\text { Rhodotorula mucilaginosa, Rhodosporidium, Cladosporium, Aspergillus, } \\
\text { Candida, Pucciniomycotina (SD) and Atheliaceae (F) }\end{array}$ & Thetis & Brine & 3415 & Mediterranean & $34^{\circ} 40.189^{\prime} \mathrm{N} 22^{\circ} 8.728^{\prime} \mathrm{E}$ & [27] \\
\hline 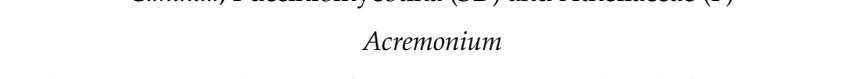 & $\begin{array}{l}\text { Thuwal brine pool } \\
\text { sediments }\end{array}$ & Brine sediments & 850 & Red sea & $22^{\circ} 16^{\prime} \mathrm{N} 38^{\circ} 53^{\prime} \mathrm{E}$ & [34] \\
\hline Malasseziomycetes (C), Microbotryomycetes (C) and Dothideomycetes (C) & Urania & Halocline & 3468 & Mediterranean & $35^{\circ} 13.784^{\prime} \mathrm{N} 21^{\circ} 42.308^{\prime} \mathrm{E}$ & [26] \\
\hline Aspergillus and Penicillium & Urania & Middle halocline & 3470 & Mediterranean & $35^{\circ} 13.784^{\prime} \mathrm{N} 21^{\circ} 42.308^{\prime} \mathrm{E}$ & [35] \\
\hline
\end{tabular}


Some of the fungal taxa found in DHABs were closely related to described species, widely distributed in the deep sea, such as the genera Rhodotorula, Cladosporium and Aspergillus. However, most of the observed fungal taxa were only distantly related to described species, which could represent novel taxa even at high taxonomic levels [36]. In addition, the hypoxic/suboxic brine layer near the Thuwal cold seeps in the Red Sea was characterised by abundant fungal taxa mostly affiliating with the Acremonium genus, which includes several saprophytic species [34]. While Thetis and Thuwal DHABs were characterised by abundant fungal genera belonging to Ascomycota [27,34], 18S rRNA analyses of some Mediterranean DHABs (i.e., Discovery, Urania, L'Atalante) showed a large number of reads affiliating to Basidiomycota, of which malasseziomycetes accounted for the largest majority [26]. Malassezia reads detected by [26] contributed to a significant proportion to the OTUs identified in the lower haloclines of both Discovery and L'Atalante. These sequences were also related to phylotypes reported from the anoxic lower halocline of the Thetis basin [27], the anoxic Cariaco Basin, the anoxic fjord Saanich Inlet [37] and deep sub-surface marine sediments of Peru Margin [38]. This cosmopolitan genus is probably of great importance in extreme deep-sea environments [26]. The diversity of habitats in which malasseziomycetes were found suggests that this group may have a variety of trophic strategies ranging from saprotrophy to biotrophy [39].

Microscopic analyses from three DHABs of the Mediterranean Sea (Discovery, Urania and L'Atalante) revealed the presence of several filamentous hyphae, which were hypothesised as belonging to fungi adapting to hypersaline environments [26,40]. In particular, several Ascomycota and Basidiomycota fungi are known to tolerate high salinity [41-43]. Fungi, as osmotolerant organisms, can balance the osmotic pressure of the surroundings by accumulating small organic molecules (i.e., glycerol, sugars, mannitol, arabitol) and thus maintaining low ion intracellular concentrations (such as $\left.\mathrm{Na}^{+}, \mathrm{Mg}^{2+}, \mathrm{Ca}^{2+}\right)[44,45]$. Particularly, halotolerant and halophilic fungi employ a strategy through which the response to stress due to increasing concentrations of organic osmolytes or salt is under the control of the high osmolarity glycerol (HOG) signalling pathway [44]. Consistently, microscopic observations also provided evidence of the presence of both yeast and filamentous fungi on bottom sediments of the oxycline and deep anoxic zones of the Black Sea [40]. Furthermore, the isolation of specimens related to Sarocladium strictum and Acremonium sp. from the brine pool adjacent to the Thual cold seep indicate that fungi might be active components of DHAB microbial assemblages [34].

So far, very little information is available on the specific eukaryotic metabolic activities in DHABs [31], even though existing methods have been proven to be reliable for the identification of eukaryotic-only transcripts (e.g., enrichment in eukaryotic transcripts in metatranscriptome data to capture a higher fraction of eukaryotic sequences). Recently, the metatranscriptomic approach has begun to blossom as a powerful method for the functional characterisation of complex microbial communities [46] and has been carried out in different ecosystems, including non-marine subsurface systems $[47,48]$, marine deep-sea sediments [49,50]. The metatranscriptomic approach has several advantages over DNA-based amplicon sequencing: It is less susceptible to amplification biases, it captures only living organisms, and provides a larger set of genes, which can be exploited for taxonomic identification [51]. In addition, the use of RNA-sequencing can reveal not only the taxonomic composition but also the active biochemical functions of microbial assemblages living in extreme environments [52]. The most critical step in such an approach is represented by the assignment of putative assembled transcripts to specific functions, as many uncultured organisms can be characterised by genomic novelties with no (or weak) similarity to genes and enzymes available in public databases [53]. The lack of fungal reference genomes and specific pipelines make analysis and interpretation of these datasets very challenging $[35,54,55]$. Therefore, the improvement and advancement of scientific technologies for deciphering fungal activity and identity in DHABs, also through the combination of multiple approaches (e.g., molecular-based and microscopic-based technologies and fungal-specific stains), are needed [56]. 
Eukaryotic metatranscriptome analyses performed on DHABs indicated that fungi are not only present but also metabolically active [26,27,31,35]. In particular, the middle and lower haloclines of the Urania and Discovery basins, respectively, were characterised by high metabolic potential, amenable to Malasseziomycetes, Dothideomycetes and Microbotryomycetes as well as to Aspergillus and Penicillium genera and various yeasts $[26,31,35]$. On the other hand, in the Discovery and Urania basins, a relevant number of transcripts indicates their saprophytic habits [35]. For example, the high expression level of a clathrin coat-binding protein of Aspergillus involved in clathrin-mediated endocytosis suggests that saprophytic fungi are active at the middle halocline of the Urania basin [35]. Up-regulation of genes related to antibiotic production, including fusaric acid production by the fungal genus Fusarium, has been reported in the upper and lower halocline of the Discovery basin and in the middle halocline of the Urania basin, suggesting that fungi in DHABs could compete with microorganisms [35]. Consistently, abundant mRNA sequences associated with the polyketide synthase enzymes, which play a key role in the production of antibiotics and participate in other secondary metabolite syntheses, were observed $[35,57]$. These results are also consistent with the high number of transcripts related to mechanisms involved in anti-microbial resistance, including drug resistance transporters, efflux pumps and multidrug resistance proteins [35,58]. Overall, these results indicate that fungi are active components of microbial assemblages even in DHAB extreme environmental conditions.

In anoxic conditions, fungi might act as a biological source of hydrogen, thus supporting the growth of hydrogen-consuming prokaryotes $[59,60]$. Moreover, in such conditions, fungi and chemoautotrophic prokaryotes might establish symbiotic relationships [59,61], enhancing the fitness of microbial communities in challenging environments, such as the DHABs.

Overall, the available literature suggests that fungi can take advantage of the high concentration of organic material in DHABs [31,32,62]. Thus they could play a role in carbon and nutrient cycling even under such extreme ecosystems [29]. In addition, since previous studies reported that competition could occur among different members of the microbial community (i.e., prokaryotes and fungi [35]), it is possible that fungi in the different matrices of DHABs (i.e., upper water column, brines and sediments) and at their interfaces can also be involved in ecological interactions with other microbes [35].

\section{Biotechnological Potential of Fungi Inhabiting DHABs}

Marine fungi are a potentially relevant source of bioactive molecules [33,63-65]. Since extremophiles show unique capabilities and adaptations, which allow them to thrive in systems characterised by harsh environmental conditions [66], halophilic and halotolerant fungi holding alternative metabolic pathways and adaptive mechanisms have important applications in industrial, pharmaceutical and environmental fields [67-69].

\subsection{DHABs as Reservoirs of Fungal Amylases, Lipases and Esterases}

Recent literature information reports that the extremophiles, such as fungi in DHABs, might produce native proteins, homologous or heterologous recombinant enzymes for several industrial applications, such as for "White Biotechnology" [70]. White Biotechnology, also defined as industrial biotechnology, exploits living cells and enzymes to synthesise bio-based products, which are readily biodegradable, thus requiring less energy and producing less waste [71]. Generally, enzymes as industrial biocatalysts offer various advantages over traditional chemical processes concerning sustainability and process efficiency [72] and are rapidly replacing chemicals counterparts [73-76].

Extremophilic marine organisms, including marine fungi, are important sources of stable and valuable enzymes [77]. Such molecules, defined "extremozymes", can carry out the same enzymatic functions as their non-extreme homologues, but they can catalyse such reactions in conditions which inhibit or denature the non-extreme forms $[78,79]$. Some of these enzymes, in the form of isolated molecules or directly produced by extremophilic fungi including those inhabiting DHABs, can display polyextremophilicity, i.e., stability and activity in more than one extreme condition, including 
high salinity $(2 \sim 5 \mathrm{M} \mathrm{NaCl})$, acid or basic $\mathrm{pH}$, high temperatures $\left(55 \sim 113{ }^{\circ} \mathrm{C}\right)$ [80]. Several marine extremozymes have been exploited for biotechnological research, whereas others for pharmaceutical, biofuel, and textile industry [81]. Despite the important results obtained in the field of research on extremophiles, the advantages of extremozymes over those of normal enzymes, the increasing demand of biotechnological industries for novel biocatalysts only a few extremozymes are currently being produced and used at the industrial level. Therefore, further scientific challenges need to be overcome before it will be possible to fully realise the potential of extremozymes [82].

Typically, high salinity tends to inactivate the enzymes by altering protein structures [83]. Therefore, the peculiar characteristics of fungal strains living in hypersaline conditions could represent a new source for exploitable enzymes able to operate at extreme $\mathrm{pH}$ and high salt concentrations (Table S1; [84]). Salt-tolerant enzymes are usually isolated from the marine environment, and halotolerant fungi show extraordinary biotechnological potential compared to enzymes isolated from their terrestrial counterparts [84]. These molecules have applications in all branches of biotechnology with significant benefits for many kinds of industries (Table 2). In particular, they are employed in the Red Biotechnology applied to pharmaceutical and medical fields (e.g., amylases, chitinase, cellulases, proteases, lipases, tannase, inulinase, esterase, methioninase, asparaginase), Grey or environmental biotechnologies (e.g., cellulase, chitinase, hydrolase, $\beta$-glucosidase, laccase, peroxidase, lipase, protease, hydrolase, $\beta$-glucanase, feruloyl esterase), and in the Blue Biotechnology applied to aquatic organisms (e.g., lipase).

As an example of biotechnological application of enzymes, $\alpha$-amylases (i.e., enzymes that catalyse the hydrolysis the $\alpha-1,4$ glycosidic linkages in amylose to release maltose and glucose, [85]) have been first produced industrially from the fungus Aspergillus oryzae, whose genus has been identified in the L'Atalante Upper halocline, Thetis brine and Urania Middle halocline, to be used as a digestive aid ([86], Table 2). Nowadays, microbial amylases commercially available have replaced chemical hydrolysis of starch in the processing industry [87]. Consistently, amylases are the most important among the enzymes of industrial interest, accounting for approximately $30 \%$ of the world enzyme market [86]. Polyextremophilic characteristics of $\alpha$-amylases from marine fungi can be exploited for biotechnological processes, being used, among others, in aquaculture, biofuel, textile, food, bakery, anti-staling, fermentation, paper-making, pharmaceutical, detergent industries [88,89]. $\alpha$-amylases can hydrolyse starch, which has attracted industrial attention for the uses as additives in food or as a natural ingredient but also for the production of renewable biofuels [79]. Although piezophilic and halophilic enzymes have a great potential for industrial applications, little information on enzymes from extreme environments is available [79]. For instance, the obligate halophilic Aspergillus penicillioides TISTR 3639, isolated from an extreme hypersaline environment is able to produce an $\alpha$-amylase, which can exhibit high catalytic activity even at extreme salt concentrations $\left(300-400 \mathrm{~g} \mathrm{~mL}^{-1} \mathrm{NaCl}\right)$, much higher than amylase activities reported from extreme halophilic marine prokaryotes as well as other halophilic organisms [90]. The potential use of extremophilic $\alpha$-amylase in the food industry was proposed by Abe and Horikoshi demonstrating that $\alpha$-amylase produces trisaccharide in place of maltobiose and tetrasaccharide, with maltooligosaccharide as substrate, at great pressure and little energy, offering great industrial and biotechnological possible applications [91]. 
Table 2. Examples of enzymes produced by fungi genera found in DHABs, and their industrial applications. Stars indicate enzymes exploited as extremozymes.

\begin{tabular}{|c|c|c|c|}
\hline Producing Fungus & Enzyme & Industrial Applications & References \\
\hline Aspergillus gracilis, A. penicillioides and A. oryzae & Amylase * & \multirow{3}{*}{$\begin{array}{c}\text { Foods, detergents, pharmaceuticals, and paper and textile } \\
\text { Biofuel production, food and feed industry, brewing, pulp and paper, } \\
\text { textile, laundry and agriculture } \\
\text { Pharmaceutical and food }\end{array}$} & {$[90,92,93]$} \\
\hline Aspergillus niger, A. sydowii and A. terreus & Cellulase * & & [94-96] \\
\hline Aspergillus terreus and Penicillium sp. & Chitinase * & & {$[97,98]$} \\
\hline $\begin{array}{c}\text { Aspergillus aculeatus, A. fumigatus, A. niger, A. terreus and } \\
\text { Penicillium canescens }\end{array}$ & $\beta$-Glucosidase * & Biofuel production, pharmaceutical and food industry & [99-103] \\
\hline $\begin{array}{l}\text { Aspergillus sclerotiorum, Cladosporium cladosporioides and } \\
\text { several strains }\end{array}$ & Laccase, Li/Mn-peroxidase & $\begin{array}{l}\text { Bioremediation, pulp biobleaching, pollutant degradation, } \\
\text { biosensors, textiles, production of bioethanol and animal feed }\end{array}$ & {$[104,105]$} \\
\hline $\begin{array}{l}\text { Candida intermedia, C. parapsilosis, C. quercitrusa, } \\
\text { Rhodotorula mucilaginosa, Aspergillus pullulans, A. awamori } \\
\text { and several strains from Antarctica }\end{array}$ & Lipase * & $\begin{array}{l}\text { Food, beverages, detergents, biofuel productions, animal feed, } \\
\text { textiles, leather, paper processing and cosmetics }\end{array}$ & [106-108] \\
\hline $\begin{array}{l}\text { Aspergillus ustus, Penicillium chrysogenum, Rhodotorula } \\
\text { mucilaginosa and several strains from Antarctica }\end{array}$ & Protease * & Bioremediation, laundry detergents, degumming of silk and leather & {$[106,109-111]$} \\
\hline $\begin{array}{c}\text { Aspergillus awamori, A. candidus, A. fumigatus and several } \\
\text { strains from Posidonia oceanica }\end{array}$ & Tannase & Food, feed, pharmaceutical, beverage, brewing and chemical & {$[105,112-115]$} \\
\hline $\begin{array}{c}\text { Aspergillus niger, A. fumigatus, A. ochraceus, A. niveus and } \\
\text { several strains from Antarctica }\end{array}$ & Xylanase * & Paper and pulp and the feed and food & {$[106,116,117]$} \\
\hline $\begin{array}{c}\text { Penicillium notatum } \\
\text { Aspergillus aculeatus, A. niger and Penicillium decumbens }\end{array}$ & $\begin{array}{l}\text { Tannin acyl hydrolase } \\
\alpha \text {-rhamnosidase }\end{array}$ & \multirow{2}{*}{$\begin{array}{c}\text { Bioremediation, leather, food and beverage } \\
\text { Food and pharmaceutical } \\
\text { Textile industry, paper recycling, detergents, beverage, animal feed } \\
\text { additives and renewable energy }\end{array}$} & $\begin{array}{c}{[118]} \\
{[119-121]}\end{array}$ \\
\hline Aspergillus fumigatus and $A$. terreus & $\beta$-glucanase & & [122-125] \\
\hline $\begin{array}{l}\text { Several strains of Aspergillus and Penicillium, } \\
\text { Candida membranifaciens and Cladosporium sp. }\end{array}$ & Inulinase & Food and pharmaceutical & [126-128] \\
\hline Aspergillus terreus & Feruloyl esterase & Food, pharmaceutical, pulp and paper, and biofuel & {$[112,129]$} \\
\hline Several strains & l-asparaginase & Food and pharmaceutical & [130] \\
\hline Several strains of Aspergillus & l-methioninase & Food and pharmaceutical & [131] \\
\hline
\end{tabular}


Lipase is a relevant enzyme with various industrial applications, which can be produced by some fungal genera found in DHABs (i.e., Aspergillus, Candida, Rhodotorula) [106-108,132]. Lipases catalyse the hydrolysis of lipids and remove fatty stains and are important compounds in the production of polyunsaturated fatty acids, food, and biodiesel [133]. In 1935, for the first time, the fungal lipase was extracted from Penicillium oxalicum and Aspergillus flavus [134]. Several genera belonging to Aspergillus and Penicillium, as well as Candida and Rhodotorula, have been encountered in many DHABs (see Table 1) [108,135], and can actively hydrolyse different oils, gaining a substantial interest due to their end-use market potential for numerous products, such as animal feeds, detergents, biosensors, diagnostic tools, oleochemicals and bioremediation agents [136,137].

In the Urania basin (Eastern Mediterranean Sea), extreme pressure, $\mathrm{pH}$ and salts can rapidly inactivate most of the known enzymes, but here, tolerant esterases were identified [138]. Esterases catalyse the hydrolysis of ester bonds in fatty acid esters with short-chain acyl groups which are harnessed in the pharmaceutical, cosmetic and food industries [139]. In particular, in the Urania basin, O.16 esterase, through mining metagenomic libraries, maintained remarkable properties as in the original environment (i.e., $180 \times$ enhanced activity at 2 to $4 \mathrm{M} \mathrm{NaCl}$ and functioning at $40 \mathrm{MPa}$; [138]).

\subsection{Fungi in DHABs as Potential Producers of Biomolecules for Pharmaceutical and Clinical Applications}

Within the area of Red Biotechnology, some investigations highlighted the potential of marine fungi to produce compounds of clinical interest with a wide array of antibacterial, anticancer, antiviral, and antioxidant applications [140-144]. In the last few decades, new antibiotics have failed due to increasing antibiotic resistance [145], and the ever-increasing demand for new natural bioactive compounds to provide benefits in all the aspects of human life has stimulated the exploration of other different Earth environments for improving the safeness and effectiveness of these molecules [146]. Compared to their terrestrial counterparts, marine fungi are understudied although they can produce a complex and diverse set of metabolites, whose functions remain largely undescribed [147].

Over the last years, marine fungi have offered new incentives for research on marine natural products for Red Biotechnology, becoming a storehouse of bioactive metabolites [65,148-151]. Since the discovery of penicillin, fungi have been established as good producers of antibiotics, which are low-molecular-weight organic natural products with antibiotic activity, which exert their effect at low concentration against other microbial organisms [152]. Fungi are considered as not only sources of antibiotics but also producers of anti-inflammatory inhibitors, anticancer drugs, and hypercholesterolemia treatment agents (Table 3). Some of the most promising molecules derived from marine fungi, particularly from deep-sea sediments, also have anti-tumoural activities. For example, a new tetranorlabdane diterpenoid, asperolide $\mathrm{E}$ was isolated from the deep-sea sediment-derived fungus Aspergillus wentii SD-310, showing cytotoxicity against cervical, breast, and lung cancer cell lines [153]. This fungal genus identified in the Discovery, L'Atalante and Urania basins, also produces Asperethers A-E, five new 20-nor-isopimarane diterpenoids, which displayed cytotoxicity toward human pulmonary adenocarcinoma cell line [153]. Aspergillus westerdijkiae SCSIO 05233 cultures isolated from deep-sea sediments in the South of China, can produce Circumdatin G, which owns antiproliferative activity against myelogenous and promyelocytic leukemia cell lines with IC50 values ranging between 25.8 and $44.9 \mu \mathrm{M}$ [154]. Similarly, Penicillium commune SD-118, whose genus was identified in DHABs (Discovery, L'Atalante and Urania), produces Xanthocillin X, chrysogine, and meleagrin which show antiproliferative and cytotoxic activities. Xanthocillin $X$ resulted in the most promising secondary metabolites extracted from this fungus for displaying an antiproliferative activity against liver, prostate, and breast cancer cell lines. Similar effects were observed with meleagrin on the prostate cancer cell line $[155,156]$. In addition, Aspergillus dimorphicus SD317, isolated from deep-sea sediments of South China Sea, whose genus identified in DHABs (i.e., L'Atalante, Thetis and Urania), produced anti-tumour agent Wentilactone A and B [157]. While Wentilactone A induced apoptosis inhibiting G2/M cell cycle through the stabilisation of the p53-p21 dimer within human lung carcinoma cells [158], Wentilactone B blocked proliferation and migration of human hepatoma 
cells [159]. Finally, one of the most important anti-cancer compounds employed for the production of drugs with an estimated value of millions of dollars is Taxol ${ }^{\circledR}$ (generic name Paclitaxel) [160]. Since its discovery in 1993 by Stierle et al. [161], many fungi showed the ability to synthesise this molecule, improving the synthesis at an industrial scale [161-163]. Interestingly, it was recently reported that Aspergillus aculeatinus Tax-6, whose genus was also found in Discovery, L'Atalante and Urania basins could increase taxol production [164].

Table 3. Examples of bioactive molecules for therapeutic use isolated from marine fungi belonging to the genera found in DHABs.

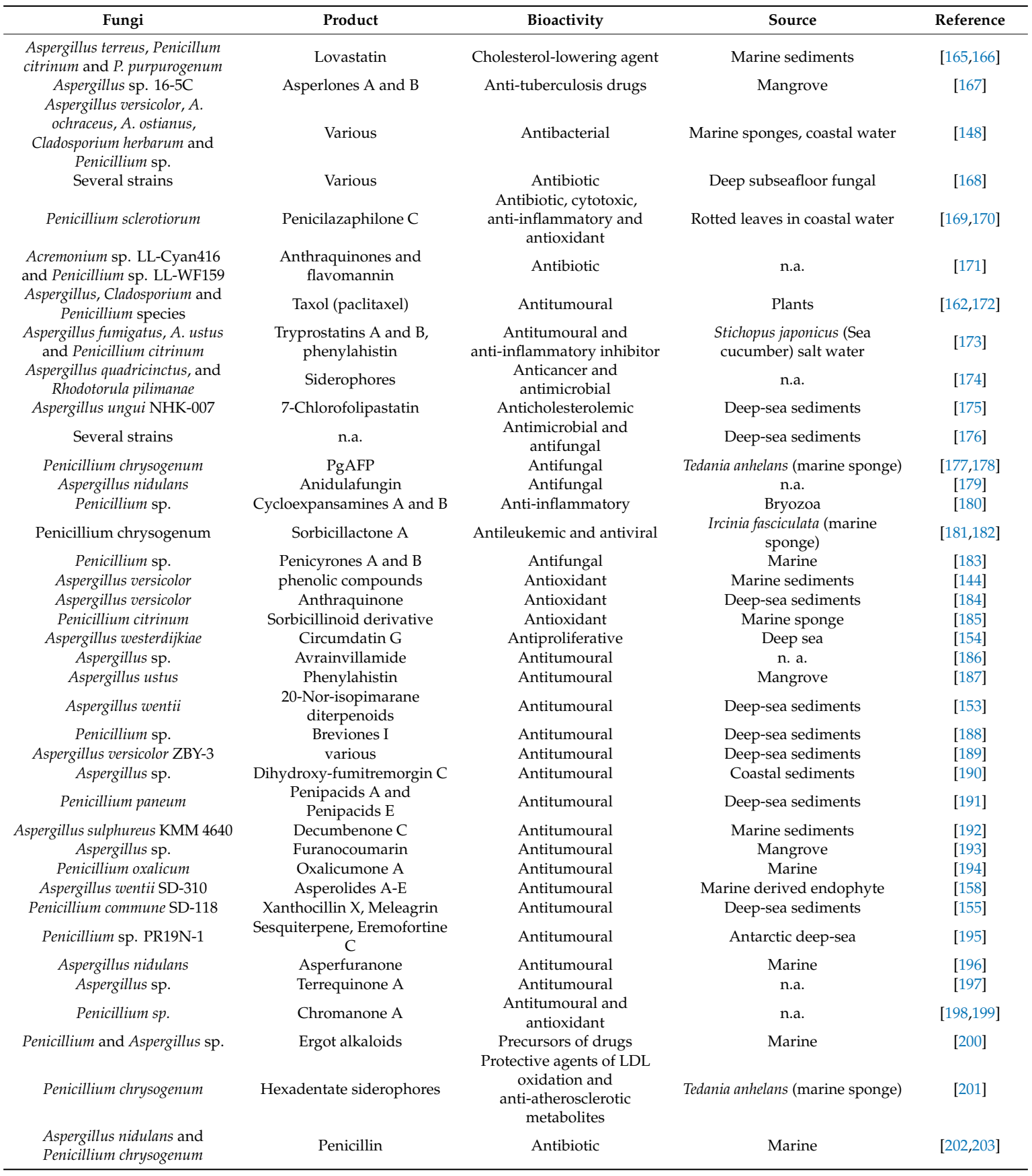

Marine fungi identified in DHABs can also produce other types of biomolecules of interest for Red Biotechnology. For instance, the isolated deep-sea fungus Aspergillus versicolor, which was also found in the Thetis basin, has shown high antifungal efficacy against human pathogens for the 
secretion of PeAfpA protein, becoming a promising candidate for its application in medicine [204]. The Aspergillus versicolor is also able to produce antioxidant compounds with potential therapeutic use or preventive agents for ROS-associated pathologies, such as neurodegenerative diseases (Alzheimer's and Parkinson's diseases) $[144,184,205]$. Other metabolites extracted from Aspergillus nidulans has shown the ability to inhibit the aggregation of tau filaments within neurons, which is the primary cause of Alzheimer's disease or other related dementias. Moreover, some intermediates produced by Candida antarctica are used for the synthesis of anti-Alzheimer's drugs [206]. ( \pm ) Asperlone A-B and (-)-mitorubrin, extracted from Aspergillus sp. 16-5C exhibited potent inhibitory activity against Mycobacterium tuberculosis protein tyrosine phosphatase B, which is encouraging for the elaboration of new anti-tuberculosis drugs [167]. Other investigations revealed that cholesterol-lowering agents extracted from fungi could inhibit the activity of HMG-CoA reductase, a key enzyme in the biosynthesis of cholesterol in the human liver, whose high levels in plasma are major risk factors for the onset of heart diseases $[207,208]$. For example, lovastatin, isolated from Aspergillus terreus was the first agent to be approved by the Food and Drug Administration (FDA, Silver Spring, MD, USA) in 1987, when it became available as a hypercholesterolemia lowering drug in the market $[166,209]$. Molecules with such properties were also isolated by other fungal strains belonging to Penicillium identified in the Atalante, Urania and Discovery DHABs ([165] and references therein).

Overall, evidence suggests that DHABs fungi may produce bioactive molecules, which can be employed as new drugs or pharmaceuticals with upgraded features (safer, more effective and with broader spectrum). The expanding number of extremophilic genomes and metagenomes from DHABs samples can provide important information for the identification of novel fungal enzymes and molecules applicable for biotechnologies.

As the biosynthesis of fungal metabolites depends on even small alterations in environmental factors, and ecological and biological interactions [210], it can be expected that DHABs differing in physical and chemical conditions and characterised by different microbial assemblages may host fungi with different biotechnological potential. This suggests that investigating the diversity and functioning of fungal assemblages in a wider array of DHABs locations and environmental settings may lead to a more complete understanding of the biotechnological potential of DHABs fungi.

\subsection{Can DHABs Fungi Be Exploited for the Bioremediation of Polluted Environments?}

Grey biotechnology is dedicated to environmental applications and focuses on recycling, treatment of waste or bioremediation purposes. Chemical and solid waste management have become an important topic of debate since the environment is being overloaded with a variety of contaminants and toxic compounds, such as polyaromatic hydrocarbons (PAHs), polychlorinated biphenyls (PCBs), polychlorinated dibenzo-p-dioxins (PCDDs), polychlorinated dibenzofurans (PCDFs) and heavy metals. However, many established methods of treatment or removal of pollutants are not conceivable for applications on a large spatial scale [211,212]. In recent years bioremediation has emerged as an environmental-friendly and cost-effectively strategy for transforming pollutants into non-dangerous products by applying natural biological processes, especially in contaminated land and water [213]. This method can be applied in polluted hypersaline environments by adding appropriate microorganisms, such as haloalkaliphilic fungi, which perform specific physical and chemical reactions as a part of their metabolism, thus degrading, removing and/or reducing the toxicity of pollutants [214,215].

Fungi represent a promising biotechnological alternative for achieving pollutants degradation or transformation into less toxic compounds with greater solubility in water, which, in turn, are degraded by the action of other microbial entities [216,217]. Absorption, degradation and accumulation are biological mechanisms employed by fungi for removing recalcitrant dyes from surrounding environments $[212,213,218]$. Moreover, halophilic fungi and their salt-tolerant enzymes (mainly lignin-degrading enzymes) seem to have great ability in bioremediation processes [219], and several fungi are well-known to degrade persistent pollutants, such as toxic dyes and PHAs [220]. As textile processes produce effluents characterised by extreme salinity and $\mathrm{pH}$ values, fungi from DHABs able to 
thrive under such conditions could represent an important biological source for bioremediation of such effluents. Fungal taxa found in DHABs can carry out dye decolourisation through oxidative reactions, which, in turn, generate non-toxic derivatives [221]. In this regard, some isolated species belonging to Aspergillus and Penicillium genera identified in the Mediterranean DHABs (see Table 1) were tested in laboratory showing decolourisation activity against Congo red dye (used in clothing manufacture, histology and microscopy), which has been reported to jeopardise the environment and the presence of an azo-functional group [222,223]. A strain of Rhodotorula mucilaginosa isolated from the Pesqueria River in Nuevo León, Mexico, and also found in the Thetis DHAB, can aid the efficient removal of another widely used and highly toxic colourant, methylene blue. This fungus, when exposed to stressful conditions in the presence of high metal concentrations produces an exopolysaccharide, which in turn can absorb methylene blue [224].

The biodegradation of organic pollutants by fungi mainly occurs through the catalytic action of extracellular enzymes released by the fungi. Lignin peroxidase and manganese peroxidase enzymes are the main extracellular enzymes purified by fungi, which are believed to be responsible for the degradation of PAHs [104]. Moreover, the laccase enzyme secreted by fungi is generally used in environmental remediation processes [225]. Laccases are copper-containing oxidases, which can transform various compounds, such as some toxic chemical wastes (e.g., polycyclic aromatic hydrocarbons, chlorinated aromatic compounds, nitroaromatics, and pesticides) and dyes, into less harmful products [226]. Moreover, three additional enzyme families are produced by fungi for bio-remediation: Esterases, glutathione S-transferases (GSTs) and cytochrome P450 monooxygenase [227]. Accounting for this enormous set of enzymes, extremophilic marine fungi are suitable for the bioremediation of polluted saline environments due to their tolerance to high-salt conditions, thus becoming an essential resource in bioremediation of marine PAH-polluted environments $[228,229]$

Some marine fungal species found in the Mediterranean and Red Sea DHABs, belonging to Aspergillus, Penicillium, Candida and Rhodotorula genera, have been reported to degrade some hydrocarbon compounds [230,231]. In particular, Rhodotorula glutinis identified in the DHAB L'Atalante has been reported to actively reduce oil compounds in petroleum polluted soils [232]. The salt-tolerant fungus, Aspergillus sclerotiorum CBMAI 849, whose genus was found in Discovery, L'Atalante and Thetis basins, showed a great ability to degrade $99.7 \%$ of pyrene and $76.6 \%$ of benzo[a]pyrene after 8 and 16 days, respectively [219]. Furthermore, it has been demonstrated that Aspergillus sclerotiorum CBMAI 849 could metabolise pyrene to pyrenylsulfate and benzo[a]pyrene to benzo[a]pyrenylsulfate, suggesting a possible implication of this fungal cytochrome P-450 monooxygenase enzyme in the detoxification of polycyclic aromatic compounds [219]. Aspergillus sp. BAP14 isolated from coastal Chinese marine sediments, and also identified in the Atalante basin was able to degrade benzo[a]pyrene, removing approximately from $30 \%$ to $60 \%$ of Pyrene and benzo[a]pyrene $\left(10 \mu \mathrm{g} \mathrm{mL}^{-1}\right)$ after 3 and 12 days, respectively [233].

Fungi inhabiting DHABs can also tolerate the presence of high concentrations of heavy metals. In particular, previous investigations revealed that species of Aspergillus and Penicillium genera showed good growth ability in the presence of arsenic, with particular regard to Aspergillus sydowii, which exhibited a remarkable tolerance toward trivalent as well as pentavalent arsenic at a concentration of $2 \mathrm{mg} \mathrm{mL}^{-1}$ [234]. This fungus is a good candidate for arsenic bioremediation for its ability to volatilise ca. $16 \%$ of supplied Arsenic (III) [212,235]. Other studies reported that Aspergillus is one of the most promising fungal genera found in DHABs for the bioremediation of heavy metals. In particular, Aspergillus niger is not only able to thrive in the presence of hexavalent chromium, but it can be employed as a biosorbent of this compound [234,236-238]

\section{Conclusions and Future Directions}

Marine fungi are a source of novel enzymes for different biotechnological applications, ranging from medicine to environmental fields. DHABs ecosystems are still largely underexplored for many 
microbial components, and data on fungal diversity and ecology in deep-sea hypersaline anoxic basins are even scanter. Therefore, the knowledge of their biotechnological applications is still limited. However, the extreme and diverse environmental features of the DHABs make these habitats unique and able to select for highly specialised organisms, which display extreme morphological, physiological and molecular adaptations. The metabolic adaptations of fungi include the ability to break down a wide range of compounds with novel enzymes, as well as the production of antibiotics, antitumoural drugs and other metabolites which can be exploited for the development of new Blue Biotechnologies. The present review provides extensive information on the biotechnological potential of fungi in DHABs, highlighting that the genera Aspergillus and Penicillium are among the most promising taxa for biotechnological applications. At the same time, this review highlights that no specific tests have been made on DHAB fungi yet. Thus, specific investigations on fungal assemblages inhabiting these peculiar systems can lead to new and unpredictable discoveries of biotechnological interest. Further scientific studies should be carried out in this direction for promoting the development of DHAB Biotechnologies.

Supplementary Materials: The following are available online at http://www.mdpi.com/1424-2818/11/7/113/s1, Table S1: Enzymes potentially produced by DHABs fungi: bioactivity and environmental conditions

Author Contributions: C.C., R.D. and A.D. conceived the study. G.B. and S.V. collected bibliographic information and available data on ecological role, diversity and biotechnological potential of marine fungi. G.B., S.V. and C.C. wrote the manuscript and all the authors, G.B., S.V., M.T., E.R., A.D., R.D., and C.C., contributed to its revision, discussion and finalisation.

Funding: This research was funded by the University Scientific Research, Italian Ministry for Education, University and Research (MIUR).

Acknowledgments: This short review was written in memory of Luigi Michaud, a colleague, a friend and a valuable marine biologist, who challenged the extreme conditions of marine environments, for the advancement of science.

Conflicts of Interest: The authors declare no conflict of interest.

\section{References}

1. Danovaro, R.; Snelgrove, P.V.R.; Tyler, P. Challenging the paradigms of deep-sea ecology. Trends Ecol. Evol. 2014, 29, 465-475. [CrossRef]

2. Van Dover, C. The Ecology of Deep-Sea Hydrothermal Vents; Princeton University Press: Princeton, NJ, USA, 2000.

3. Danovaro, R.; Corinaldesi, C.; Dell'Anno, A.; Snelgrove, P.V.R. The deep-sea under global change. Curr. Biol. 2017, 27, R461-R465. [CrossRef]

4. Charnock, H. Anomalous bottom water in the Red Sea. Nature 1964, 203, 591. [CrossRef]

5. Backer, H.; Schoell, M. New Deeps with Brines and Metalliferous Sediments in the Red Sea. Nat. Phys. Sci. 1972, 240, 153-158. [CrossRef]

6. Merlino, G.; Barozzi, A.; Michoud, G.; Ngugi, D.K.; Daffonchio, D. Microbial ecology of deep-sea hypersaline anoxic basins. FEMS Microbiol. Ecol. 2018, 94. [CrossRef]

7. Cita, M.B. Exhumation of Messinian evaporites in the deep-sea and creation of deep anoxic brine-filled collapsed basins. Sediment. Geol. 2006, 188-189, 357-378. [CrossRef]

8. Edgcomb, V.P.; Orsi, W.; Breiner, H.W.; Stock, A.; Filker, S.; Yakimov, M.M.; Stoeck, T. Novel active kinetoplastids associated with hypersaline anoxic basins in the Eastern Mediterranean deep-sea. Deep Sea Res. Part I Oceanogr. Res. Pap. 2011, 58, 1040-1048. [CrossRef]

9. La Cono, V.; Smedile, F.; Bortoluzzi, G.; Arcadi, E.; Maimone, G.; Messina, E.; Borghini, M.; Oliveri, E.; Mazzola, S.; L'Haridon, S.; et al. Unveiling microbial life in new deep-sea hypersaline Lake Thetis. Part I: Prokaryotes and environmental settings. Environ. Microbiol. 2011, 13, 2250-2268. [CrossRef]

10. van der Wielen, P.W.J.J.; Bolhuis, H.; Borin, S.; Daffonchio, D.; Corselli, C.; Giuliano, L.; D'Auria, G.; de Lange, G.J.; Huebner, A.; Varnavas, S.P.; et al. The enigma of prokaryotic life in deep hypersaline anoxic basins. Science 2005, 307, 121-123. [CrossRef]

11. Wallmann, K.; Suess, E.; Westbrook, G.H.; Winckler, G.; Cita, M.B. Salty brines on the Mediterranean sea floor. Nature 1997, 387, 31-32. [CrossRef] 
12. Alexander, E.; Stock, A.; Breiner, H.W.; Behnke, A.; Bunge, J.; Yakimov, M.M.; Stoeck, T. Microbial eukaryotes in the hypersaline anoxic L'Atalante deep-sea basin. Environ. Microbiol. 2009, 11, 360-381. [CrossRef]

13. Danovaro, R.; Dell'Anno, A.; Pusceddu, A.; Gambi, C.; Heiner, I.; Kristensen, R.M. The first metazoa living in permanently anoxic conditions. BMC Biol. 2010, 8, 30. [CrossRef]

14. Eder, W.; Ludwig, W.; Huber, R. Novel 16S rRNA gene sequences retrieved from highly saline brine sediments of Kebrit Deep, Red Sea. Arch. Microbiol. 1999, 172, 213-218. [CrossRef]

15. Eder, W.; Jahnke, L.L.; Schmidt, M.; Huber, R. Microbial Diversity of the Brine-Seawater Interface of the Kebrit Deep, Red Sea, Studied via 16S rRNA Gene Sequences and Cultivation Methods. Appl. Environ. Microbiol. 2001, 67, 3077-3085. [CrossRef]

16. Eder, W.; Schmidt, M.; Koch, M.; Garbe-Schönberg, D.; Huber, R. Prokaryotic phylogenetic diversity and corresponding geochemical data of the brine-seawater interface of the Shaban Deep, Red Sea. Environ. Microbiol. 2002, 4, 758-763. [CrossRef]

17. Sass, A.M.; Sass, H.; Coolen, M.J.L.; Cypionka, H.; Overmann, J. Microbial Communities in the Chemocline of a Hypersaline Deep-Sea Basin (Urania Basin, Mediterranean Sea). Appl. Environ. Microbiol. 2001, 67, 5392-5402. [CrossRef]

18. van der Wielen, P.W.J.J.; Heijs, S.K. Sulfate-reducing prokaryotic communities in two deep hypersaline anoxic basins in the Eastern Mediterranean deep sea. Environ. Microbiol. 2007, 9, 1335-1340. [CrossRef]

19. Yakimov, M.M.; Giuliano, L.; Cappello, S.; Denaro, R.; Golyshin, P.N. Microbial community of a hydrothermal mud vent underneath the deep-sea anoxic brine Lake Urania (eastern Mediterranean). Orig. LIFE Evol. Biosph. 2007, 37, 177-188. [CrossRef]

20. Edgcomb, V.; Orsi, W.; Leslin, C.; Epstein, S.S.; Bunge, J.; Jeon, S.; Yakimov, M.M.; Behnke, A.; Stoeck, T. Protistan community patterns within the brine and halocline of deep hypersaline anoxic basins in the eastern Mediterranean Sea. Extremophiles 2009, 13, 151-167. [CrossRef]

21. Hallsworth, J.E.; Yakimov, M.M.; Golyshin, P.N.; Gillion, J.L.M.; D’Auria, G.; De Lima Alves, F.; La Cono, V.; Genovese, M.; McKew, B.A.; Hayes, S.L.; et al. Limits of life in $\mathrm{MgCl}_{2}$-containing environments: Chaotropicity defines the window. Environ. Microbiol. 2007, 9, 801-813. [CrossRef]

22. Steinle, L.; Knittel, K.; Felber, N.; Casalino, C.; de Lange, G.; Tessarolo, C.; Stadnitskaia, A.; Sinninghe Damsté, J.S.; Zopfi, J.; Lehmann, M.F.; et al. Life on the edge: Active microbial communities in the Kryos $\mathrm{MgCl} 2$-brine basin at very low water activity. ISME J. 2018, 12, 1414-1426. [CrossRef]

23. Yakimov, M.M.; La Cono, V.; Denaro, R.; D'Auria, G.; Decembrini, F.; Timmis, K.N.; Golyshin, P.N.; Giuliano, L. Primary producing prokaryotic communities of brine, interface and seawater above the halocline of deep anoxic lake L'Atalante, Eastern Mediterranean Sea. ISME J. 2007, 1, 743-755. [CrossRef]

24. Ngugi, D.K.; Blom, J.; Alam, I.; Rashid, M.; Ba-Alawi, W.; Zhang, G.; Hikmawan, T.; Guan, Y.; Antunes, A.; Siam, R.; et al. Comparative genomics reveals adaptations of a halotolerant thaumarchaeon in the interfaces of brine pools in the Red Sea. ISME J. 2015, 9, 396-411. [CrossRef]

25. Antunes, A.; Ngugi, D.K.; Stingl, U. Microbiology of the Red Sea (and other) deep-sea anoxic brine lakes. Environ. Microbiol. Rep. 2011, 3, 416-433. [CrossRef]

26. Bernhard, J.M.; Kormas, K.; Pachiadaki, M.G.; Rocke, E.; Beaudoin, D.J.; Morrison, C.; Visscher, P.T.; Cobban, A.; Starczak, V.R.; Edgcomb, V.P. Benthic protists and fungi of Mediterranean deep hypsersaline anoxic basin redoxcline sediments. Front. Microbiol. 2014, 5, 1-13. [CrossRef]

27. Stock, A.; Breiner, H.W.; Pachiadaki, M.; Edgcomb, V.; Filker, S.; La Cono, V.; Yakimov, M.M.; Stoeck, T. Microbial eukaryote life in the new hypersaline deep-sea basin Thetis. Extremophiles 2012, 16, 21-34. [CrossRef]

28. Valiela, I. Marine Ecological Processes; Springer: Berlin, Germany, 2016.

29. Grossart, H.P.; Van den Wyngaert, S.; Kagami, M.; Wurzbacher, C.; Cunliffe, M.; Rojas-Jimenez, K. Fungi in aquatic ecosystems. Nat. Rev. Microbiol. 2019, 1-16. [CrossRef]

30. Fungi in Biogeochemical Cycles; Gadd, G.M. (Ed.) Cambridge University Press: Cambridge, UK, 2006.

31. Pachiadaki, M.G.; Yakimov, M.M.; Lacono, V.; Leadbetter, E.; Edgcomb, V. Unveiling microbial activities along the halocline of Thetis, a deep-sea hypersaline anoxic basin. ISME J. 2014, 8, 2478-2489. [CrossRef]

32. Cantrell, S.A.; Casillas-Martínez, L.; Molina, M. Characterization of fungi from hypersaline environments of solar salterns using morphological and molecular techniques. Mycol. Res. 2006, 110, 962-970. [CrossRef]

33. Corinaldesi, C.; Barone, G.; Marcellini, F.; Dell'Anno, A.; Danovaro, R. Marine microbial-derived molecules and their potential use in cosmeceutical and cosmetic products. Mar. Drugs 2017, 15, 118. [CrossRef] 
34. Wang, Y.; Zhang, W.P.; Cao, H.L.; Shek, C.S.; Tian, R.M.; Wong, Y.H.; Batang, Z.; Al-Suwailem, A.; Qian, P.Y.Y. Diversity and distribution of eukaryotic microbes in and around a brine pool adjacent to the Thuwal cold seeps in the Red Sea. Front. Microbiol. 2014, 5, 1-10. [CrossRef]

35. Edgcomb, V.P.; Pachiadaki, M.G.; Mara, P.; Kormas, K.A.; Leadbetter, E.R.; Bernhard, J.M. Gene expression profiling of microbial activities and interactions in sediments under haloclines of E. Mediterranean deep hypersaline anoxic basins. ISME J. 2016, 10, 2643-2657. [CrossRef]

36. Reich, M.; Labes, A. How to boost marine fungal research: A first step towards a multidisciplinary approach by combining molecular fungal ecology and natural products chemistry. Mar. Genom. 2017, 36, 57-75. [CrossRef]

37. Orsi, W.; Song, Y.C.; Hallam, S.; Edgcomb, V. Effect of oxygen minimum zone formation on communities of marine protists. ISME J. 2012, 6, 1586-1601. [CrossRef]

38. Edgcomb, V.P.; Beaudoin, D.; Gast, R.; Biddle, J.F.; Teske, A. Marine subsurface eukaryotes: the fungal majority. Environ. Microbiol. 2011, 13, 172-183. [CrossRef]

39. Amend, A. From Dandruff to Deep-Sea Vents: Malassezia-like Fungi Are Ecologically Hyper-diverse. PLoS Pathog. 2014, 10, e1004277. [CrossRef]

40. Sergeeva, N.G.; Kopytina, N.I. The first marine filamentous fungi discovered in the bottom sediments of the oxic/anoxic interface and in the bathyal zone of the black sea. Turk. J. Fish. Aquat. Sci. 2014, 14, 497-505. [CrossRef]

41. Gunde-Cimerman, N.; Zalar, P.; De Hoog, S.; Plemenitaš, A. Hypersaline waters in salterns-Natural ecological niches for halophilic black yeasts. FEMS Microbiol. Ecol. 2000, 32, 235-240.

42. Gunde-Cimerman, N.; Plemenitaš, A.; Oren, A. Strategies of adaptation of microorganisms of the three domains of life to high salt concentrations. FEMS Microbiol. Rev. 2018, 42, 353-375. [CrossRef]

43. Gunde-Cimerman, N.; Oren, A.; Plemenitaš, A. Adaptation to Life at High Salt Concentrations in Archaea, Bacteria, and Eukarya. In Cellular Origin, Life in Extreme Habitats and Astrobiology; Gunde-Cimerman, N., Oren, A., Plemenitaš, A., Eds.; Springer: Dordrecht, The Netherlands, 2005; Volume 9.

44. Gostinčar, C.; Lenassi, M.; Gunde-Cimerman, N.; Plemenitaš, A. Fungal Adaptation to Extremely High Salt Concentrations. Adv. Appl. Microbiol. 2011, 77, 71-96.

45. Zajc, J.; Džeroski, S.; Kocev, D.; Oren, A.; Sonjak, S.; Tkavc, R.; Gunde-Cimerman, N. Chaophilic or chaotolerant fungi: A new category of extremophiles? Front. Microbiol. 2014, 5, 1-15. [CrossRef]

46. Jiang, Y.; Xiong, X.; Danska, J.; Parkinson, J. Metatranscriptomic analysis of diverse microbial communities reveals core metabolic pathways and microbiome-specific functionality. Microbiome 2016, 4, 2. [CrossRef]

47. Pachiadaki, M.G.; Taylor, C.; Oikonomou, A.; Yakimov, M.M.; Stoeck, T.; Edgcomb, V. In situ grazing experiments apply new technology to gain insights into deep-sea microbial food webs. Deep Sea Res. Part II Top. Stud. Oceanogr. 2016, 129, 223-231. [CrossRef]

48. Lopez-Fernandez, M.; Simone, D.; Wu, X.; Soler, L.; Nilsson, E.; Holmfeldt, K.; Lantz, H.; Bertilsson, S.; Dopson, M. Metatranscriptomes Reveal That All Three Domains of Life Are Active but Are Dominated by Bacteria in the Fennoscandian Crystalline Granitic Continental Deep Biosphere. MBio 2018, 9, e01792-18. [CrossRef]

49. Orsi, W.; Biddle, J.F.; Edgcomb, V. Deep Sequencing of Subseafloor Eukaryotic rRNA Reveals Active Fungi across Marine Subsurface Provinces. PLoS ONE 2013, 8, e56335. [CrossRef]

50. Orsi, W.D.; Barker Jørgensen, B.; Biddle, J.F. Transcriptional analysis of sulfate reducing and chemolithoautotrophic sulfur oxidizing bacteria in the deep subseafloor. Environ. Microbiol. Rep. 2016, 8, 452-460. [CrossRef]

51. Glaeser, S.P.; Kämpfer, P. The Family Sphingomonadaceae. In The Prokaryotes; Springer: Berlin, Heidelberg, Germany, 2014; pp. 641-707, ISBN 9783642301.

52. Lau, M.C.Y.; Harris, R.L.; Oh, Y.; Yi, M.J.; Behmard, A.; Onstott, T.C. Taxonomic and functional compositions impacted by the quality of metatranscriptomic assemblies. Front. Microbiol. 2018, 9, 1-17. [CrossRef]

53. Celaj, A.; Markle, J.; Danska, J.; Parkinson, J. Comparison of assembly algorithms for improving rate of metatranscriptomic functional annotation. Microbiome 2014, 2, 39. [CrossRef]

54. Loeffler, C.; Karlsberg, A.; Eskin, E.; Koslicki, D.; Mangul, S. Analysis of multiple fungal sequence repositories highlights shortcomings in microbial databases. BioRxiv 2019. [CrossRef]

55. Moreton, J.; Izquierdo, A.; Emes, R.D. Assembly, assessment, and availability of De novo generated eukaryotic transcriptomes. Front. Genet. 2016, 6, 1-9. [CrossRef] 
56. Barone, G.; Rastelli, E.; Corinaldesi, C.; Tangherlini, M.; Danovaro, R.; Dell'Anno, A. Benthic deep-sea fungi in submarine canyons of the Mediterranean Sea. Prog. Oceanogr. 2018, 168, 57-64. [CrossRef]

57. Koehn, F.E.; Carter, G.T. The evolving role of natural products in drug discovery. Nat. Rev. Drug Discov. 2005, 4, 206-220. [CrossRef]

58. Rahman, T.; Yarnall, B.; Doyle, D.A. Efflux drug transporters at the forefront of antimicrobial resistance. Eur. Biophys. J. 2017, 46, 647-653. [CrossRef]

59. Ivarsson, M.; Schnürer, A.; Bengtson, S.; Neubeck, A. Anaerobic fungi: A potential source of biological H2 in the oceanic crust. Front. Microbiol. 2016, 7, 674. [CrossRef]

60. Kruse, S.; Goris, T.; Westermann, M.; Adrian, L.; Diekert, G. Hydrogen production by Sulfurospirillum species enables syntrophic interactions of Epsilonproteobacteria. Nat. Commun. 2018, 9, 4872. [CrossRef]

61. Bengtson, S.; Ivarsson, M.; Astolfo, A.; Belivanova, V.; Broman, C.; Marone, F.; Stampanoni, M. Deep-biosphere consortium of fungi and prokaryotes in Eocene subseafloor basalts. Geobiology 2014, 12, 489-496. [CrossRef]

62. Danovaro, R.; Corinaldesi, C.; Dell'Anno, A.; Fabiano, M.; Corselli, C. Viruses, prokaryotes and DNA in the sediments of a deep-hypersaline anoxic basin (DHAB) of the Mediterranean Sea. Environ. Microbiol. 2005, 7 , 586-592. [CrossRef]

63. Corinaldesi, C. New perspectives in benthic deep-sea microbial ecology. Front. Mar. Sci. 2015, 2, 1-12. [CrossRef]

64. Chambergo, F.S.; Valencia, E.Y. Fungal biodiversity to biotechnology. Appl. Microbiol. Biotechnol. 2016, 100, 2567-2577. [CrossRef]

65. Deshmukh, S.K.; Prakash, V.; Ranjan, N. Marine Fungi: A Source of Potential Anticancer Compounds. Potential Anticancer Compd. Front. Microbiol. 2018, 8, 2536. [CrossRef]

66. Coker, J.A. Extremophiles and biotechnology: Current uses and prospects. F1000Research 2016, 5, $396-403$. [CrossRef]

67. Gunde-Cimerman, N.; Zalar, P. Extremely halotolerant and halophilic fungi inhabit brine in solar salterns around the globe. Food Technol. Biotechnol. 2014, 52, 170-179.

68. Nicoletti, R.A.A. The Marine-Derived Filamentous Fungi in Biotechnology. In Grand Challenges in Biology and Biotechnology; Rampelotto Pabulo, H., Ed.; Springer Nature: Basingstoke, UK, 2018; pp. 157-189.

69. Plemenitaš, A.; Lenassi, M.; Konte, T.; Kejžar, A.; Zajc, J.; Gostinčar, C.; Gunde-Cimerman, N. Adaptation to high salt concentrations in halotolerant/halophilic fungi: A molecular perspective. Front. Microbiol. 2014, 5 , 1-12. [CrossRef]

70. Di Donato, P.; Buono, A.; Poli, A.; Finore, I.; Abbamondi, G.; Nicolaus, B.; Lama, L. Exploring Marine Environments for the Identification of Extremophiles and Their Enzymes for Sustainable and Green Bioprocesses. Sustainability 2019, 11, 149. [CrossRef]

71. Frazzetto, G. White biotechnology. EMBO Rep. 2003, 4, 835-837.

72. Chapman, J.; Ismail, A.; Dinu, C. Industrial Applications of Enzymes: Recent Advances, Techniques, and Outlooks. Catalysts 2018, 8, 238. [CrossRef]

73. Bommarius, A.S.; Paye, M.F. Stabilizing biocatalysts. Chem. Soc. Rev. 2013, 42, 6534-6565. [CrossRef]

74. Madhavan, A.; Sindhu, R.; Binod, P.; Sukumaran, R.K.; Pandey, A. Strategies for design of improved biocatalysts for industrial applications. Bioresour. Technol. 2017, 245, 1304-1313. [CrossRef]

75. Prasad, S.; Roy, I. Converting Enzymes into Tools of Industrial Importance. Recent Pat. Biotechnol. 2018, 12, 33-56. [CrossRef]

76. Choi, J.M.; Han, S.S.; Kim, H.S. Industrial applications of enzyme biocatalysis: Current status and future aspects. Biotechnol. Adv. 2015, 33, 1443-1454. [CrossRef]

77. Zhang, X.; Li, S.J.; Li, J.J.; Liang, Z.Z.; Zhao, C.Q. Novel natural products from extremophilic fungi. Mar. Drugs 2018, 16, 194. [CrossRef]

78. Adams, M.W.W.; Perler, F.B.; Kelly, R.M. Extremozymes: Expanding the Limits of Biocatalysis. Nat. Biotechnol. 1995, 13, 662-668. [CrossRef]

79. Dumorné, K.; Córdova, D.C.; Astorga-Eló, M.; Renganathan, P. Extremozymes: A potential source for industrial applications. J. Microbiol. Biotechnol. 2017, 27, 649-659. [CrossRef]

80. Dalmaso, G.; Ferreira, D.; Vermelho, A. Marine Extremophiles: A Source of Hydrolases for Biotechnological Applications. Mar. Drugs 2015, 13, 1925-1965. [CrossRef] 
81. Suriya, J.; Bharathiraja, S.; Krishnan, S.; Manivasagan, P. Extremozyme from Marine Actinobacteria. In Marine Enzymes Biotechnology: Production and Industrial Applications, Part II-Marine Organisms Producing Enzymes; Elsevier: Amsterdam, The Netherlands, 2016; pp. 43-66.

82. Sarmiento, F.; Peralta, R.; Blamey, J.M. Cold and Hot Extremozymes: Industrial Relevance and Current Trends. Front. Bioeng. Biotechnol. 2015, 3. [CrossRef]

83. Stigter, D.; Alonso, D.O.V.; Dill, K.A. Protein stability: Electrostatics and compact denatured states. Proc. Natl. Acad. Sci. USA 1991, 88, 4176-4180. [CrossRef]

84. Bonugli-Santos, R.C.; Vasconcelos, M.R.; dos, S.; Passarini, M.R.Z.; Vieira, G.A.L.; Lopes, V.C.P.; Mainardi, P.H.; Duarte, L.; Otero, I.V.R.; Yoshida, A.M.; et al. Marine-derived fungi: Diversity of enzymes and biotechnological applications. Front. Microbiol. 2015, 6, 1-15.

85. Gupta, R.; Gigras, P.; Mohapatra, H.; Goswami, V.K.; Chauhan, B. Microbial $\alpha$-amylases: A biotechnological perspective. Process Biochem. 2003, 38, 1599-1616. [CrossRef]

86. Sivaramakrishnan, S.; Gangadharan, D.; Nampoothiri, K.M.; Soccol, C.R.; Pandey, A. $\alpha$-Amylases from microbial sources-An overview on recent developments. Food Technol. Biotechnol. 2006, 44, 173-184.

87. de Souza, P.M.; de Oliveira Magalhães, P. Application of microbial $\alpha$-amylase in industry-A review. Braz. J. Microbiol. 2010, 41, 850-861. [CrossRef]

88. Suriya, J.; Bharathiraja, S.; Krishnan, M.; Manivasagan, P.; Kim, S.K. Marine Microbial Amylases. In Advances in Food and Nutrition Research; Elsevier: Amsterdam, The Netherlands, 2016; Volume 79, pp. 161-177.

89. Gopinath, S.C.B.; Anbu, P.; Arshad, M.K.M.; Lakshmipriya, T.; Voon, C.H.; Hashim, U.; Chinni, S. V Biotechnological Processes in Microbial Amylase Production. BioMed Res. Int. 2017, 2017, 1-9. [CrossRef]

90. Ali, I.; Akbar, A.; Anwar, M.; Prasongsuk, S.; Lotrakul, P.; Punnapayak, H. Purification and characterization of a polyextremophilic $\alpha$-Amylase from an obligate halophilic Aspergillus penicillioides isolate and its potential for souse with detergents. BioMed Res. Int. 2015, 2015, 1-8.

91. Abe, F.; Horikoshi, K. The biotechnological potential of piezophiles. Trends Biotechnol. 2001, 19, 102-108. [CrossRef]

92. Ali, I.; Akbar, A.; Yanwisetpakdee, B.; Prasongsuk, S.; Lotrakul, P.; Punnapayak, H. Purification, characterization, and potential of saline waste water remediation of a polyextremophilic $\alpha$-amylase from an obligate halophilic Aspergillus gracilis. BioMed Res. Int. 2014, 2014, 1-7. [CrossRef]

93. Carlsen, M.; Nielsen, J. Influence of carbon source on $\alpha$-amylase production by Aspergillus oryzae. Appl. Microbiol. Biotechnol. 2001, 57, 346-349. [CrossRef]

94. Bansal, N.; Tewari, R.; Soni, R.; Soni, S.K. Production of cellulases from Aspergillus niger NS-2 in solid state fermentation on agricultural and kitchen waste residues. Waste Manag. 2012, 32, 1341-1346. [CrossRef]

95. Padmavathi, T.; Nandy, V.; Agarwal, P. Optimization of the medium for the production of cellulases by Aspergillus terreus and Mucor plumbeus. Eur. J. Exp. Biol. 2012, 2, 1161-1170.

96. Liu, J.; Xue, D.; He, K.; Yao, S. Cellulase production in solid-state fermentation by marine Aspergillus ZJUBE-1 and Its enzymological properties. Adv. Sci. Lett. 2012, 16, 381-386. [CrossRef]

97. Farag, A.M.; Abd-Elnabey, H.M.; Ibrahim, H.A.H.; El-Shenawy, M. Purification, characterization and antimicrobial activity of chitinase from marine-derived Aspergillus terreus. Egypt. J. Aquat. Res. 2016, 42, 185-192. [CrossRef]

98. Bradner, J.R.; Gillings, M.; Nevalainen, K.M.H. Qualitative assessment of hydrolytic activities in antarctic microfungi grown at different temperatures on solid media. J. Microbiol. 1999, 15, 131-132.

99. Baba, Y.; Sumitani, J.; Tani, S.; Kawaguchi, T. Characterization of Aspergillus aculeatus $\beta$-glucosidase 1 accelerating cellulose hydrolysis with Trichoderma cellulase system. AMB Express 2015, 5, 1-9. [CrossRef]

100. Das, A.; Paul, T.; Ghosh, P.; Halder, S.K.; Das Mohapatra, P.K.; Pati, B.R.; Mondal, K.C. Kinetic Study of a Glucose Tolerant $\beta$-Glucosidase from Aspergillus fumigatus ABK9 Entrapped into Alginate Beads. Waste Biomass Valoriz. 2015, 6, 53-61. [CrossRef]

101. Xue, D.S.; Chen, H.Y.; Ren, Y.R.; Yao, S.J. Enhancing the activity and thermostability of thermostable $\beta$-glucosidase from a marine Aspergillus niger at high salinity. Process Biochem. 2012, 47, 606-611. [CrossRef]

102. Giraldo, M.A.; Gonçalves, H.B.; Furriel, R.; dos, P.M.; Jorge, J.A.; Guimarães, L.H.S. Characterization of the co-purified invertase and $\beta$-glucosidase of a multifunctional extract from Aspergillus terreus. World J. Microbiol. Biotechnol. 2014, 30, 1501-1510. [CrossRef] 
103. Dubrovskaya, Y.V.; Sova, V.V.; Slinkina, N.N.; Anastyuk, S.D.; Pivkin, M.V.; Zvyagintseva, T.N. Extracellular $\beta$-D-glucosidase of the Penicillium canescens marine fungus. Appl. Biochem. Microbiol. 2012, 48, 401-408. [CrossRef]

104. Bonugli-Santos, R.C.; Durrant, L.R.; da Silva, M.; Sette, L.D. Production of laccase, manganese peroxidase and lignin peroxidase by Brazilian marine-derived fungi. Enzyme Microb. Technol. 2010, 46, 32-37. [CrossRef]

105. Panno, L.; Bruno, M.; Voyron, S.; Anastasi, A.; Gnavi, G.; Miserere, L.; Varese, G.C. Diversity, ecological role and potential biotechnological applications of marine fungi associated to the seagrass Posidonia oceanica. New Biotechnol. 2013, 30, 685-694. [CrossRef]

106. Duarte, A.W.F.; Dayo-Owoyemi, I.; Nobre, F.S.; Pagnocca, F.C.; Chaud, L.C.S.; Pessoa, A.; Felipe, M.G.A.; Sette, L.D. Taxonomic assessment and enzymes production by yeasts isolated from marine and terrestrial Antarctic samples. Extremophiles 2013, 17, 1023-1035. [CrossRef]

107. Basheer, S.M.; Chellappan, S.; Beena, P.S.S.; Sukumaran, R.K.; Elyas, K.K.K.; Chandrasekaran, M. Lipase from marine Aspergillus awamori BTMFW032: Production, partial purification and application in oil effluent treatment. New Biotechnol. 2011, 28, 627-638. [CrossRef]

108. Wang, L.; Chi, Z.; Wang, X.; Liu, Z.; Li, J. Diversity of lipase-producing yeasts from marine environments and oil hydrolysis by their crude enzymes. Ann. Microbiol. 2009, 57, 495-501. [CrossRef]

109. Damare, S.; Raghukumar, C.; Muraleedharan, U.D.; Raghukumar, S. Deep-sea fungi as a source of alkaline and cold-tolerant proteases. Enzyme Microb. Technol. 2006, 39, 172-181. [CrossRef]

110. Zhu, H.Y.; Tian, Y.; Hou, Y.H.; Wang, T.H. Purification and characterization of the cold-active alkaline protease from marine cold-adaptive Penicillium chrysogenum FS010. Mol. Biol. Rep. 2009, 36, 2169-2174. [CrossRef]

111. Chaud, L.C.; Lario, L.D.; Bonugli-Santos, R.C.; Sette, L.D.; Pessoa Junior, A. Improvement in extracellular protease production by the marine antarctic yeast Rhodotorula mucilaginosa L7. New Biotechnol. 2016, 33, 807-814. [CrossRef]

112. Cavalcanti, R.M.F.; Jorge, J.A.; Guimarães, L.H.S. Characterization of Aspergillus fumigatus CAS-21 tannase with potential for propyl gallate synthesis and treatment of tannery effluent from leather industry. 3 Biotech 2018, 8, 1-11. [CrossRef]

113. Murugan, K.; Al-Sohaiba, S.A. Biocompatible Removal of Tannin and Associated Color from Tannery Effluent using the Biomass and Tannin Acyl Hydrolase (E.C.3.1.1.20) Enzymes of Mango Industry Solid Waste Isolate Aspergillus candidus MTTC 9628. Res. J. Microbiol. 2010, 5, 262-271. [CrossRef]

114. Beena, P.S.; Basheer, S.M.; Bhat, S.G.; Bahkali, A.H.; Chandrasekaran, M. Propyl Gallate Synthesis Using Acidophilic Tannase and Simultaneous Production of Tannase and Gallic Acid by Marine Aspergillus awamori BTMFW032. Appl. Biochem. Biotechnol. 2011, 164, 612-628. [CrossRef]

115. Beena, P.S.; Soorej, M.B.; Elyas, K.K.; Sarita, G.B.; Chandrasekaran, M. Acidophilic tannase from marine Aspergillus awamori BTMFW032. J. Microbiol. Biotechnol. 2010, 20, 1403-1414. [CrossRef]

116. Raghukumar, C.; Muraleedharan, U.; Gaud, V.R.; Mishra, R. Xylanases of marine fungi of potential use for biobleaching of paper pulp. J. Ind. Microbiol. Biotechnol. 2004, 31, 433-441. [CrossRef]

117. Sridevi, A.; Sandhya, A.; Ramanjaneyulu, G.; Narasimha, G.; Devi, P.S. Biocatalytic activity of Aspergillus niger xylanase in paper pulp biobleaching. 3 Biotech 2016, 6, 165. [CrossRef]

118. Gayen, S.; Ghosh, U. Purification and characterization of tannin acyl hydrolase produced by mixed solid state fermentation of wheat bran and marigold flower by Penicillium notatum NCIM 923. BioMed Res. Int. 2013, 2013, 1-6. [CrossRef]

119. Manzanares, P.; Van Den Broeck, H.C.; De Graaff, L.H.; Visser, J. Purification and Characterization of Two Different $\alpha$-L-Rhamnosidases, RhaA and RhaB, from Aspergillus aculeatus. Appl. Environ. Microbiol. 2001, 67, 2230-2234. [CrossRef]

120. Li, L.; Yu, Y.; Zhang, X.; Jiang, Z.; Zhu, Y.; Xiao, A.; Ni, H.; Chen, F. Expression and biochemical characterization of recombinant $\alpha$-l-rhamnosidase r-Rha1 from Aspergillus niger JMU-TS528. Int. J. Biol. Macromol. 2016, 85, 391-399. [CrossRef]

121. Young, N.M.; Johnston, R.A.Z.; Richards, J.C. Purification of the $\alpha$-l-rhamnosidase of Penicillium decumbens and characterisation of two glycopeptide components. Carbohydr. Res. 1989, 191, 53-62. [CrossRef]

122. Bernardi, A.V.; de Gouvêa, P.F.; Gerolamo, L.E.; Yonamine, D.K.; de Lourdes de Lima Balico, L.; Uyemura, S.A.; Dinamarco, T.M. Functional characterization of GH7 endo-1,4- $\beta$-glucanase from Aspergillus fumigatus and its potential industrial application. Protein Expr. Purif. 2018, 150, 1-11. [CrossRef] 
123. Elshafei, A.M.; Hassan, M.M.; Haroun, B.M.; Abdel-Fatah, O.M.; Atta, H.M.; Othman, A.M. Purification and properties of an endoglucanase of Aspergillus terreus DSM 826. J. Basic Microbiol. 2009, 49, 426-432. [CrossRef]

124. Narra, M.; Dixit, G.; Divecha, J.; Kumar, K.; Madamwar, D.; Shah, A.R. Production, purification and characterization of a novel GH 12 family endoglucanase from Aspergillus terreus and its application in enzymatic degradation of delignified rice straw. Int. Biodeterior. Biodegrad. 2014, 88, 150-161. [CrossRef]

125. Segato, F.; Berto, G.L.; Ares de Araújo, E.; Muniz, J.R.; Polikarpov, I. IUCr Expression, purification, crystallization and preliminary $\mathrm{X}$-ray diffraction analysis of Aspergillus terreus endo- $\beta$-1,4-glucanase from glycoside hydrolase family 12. Acta Crystallogr. Sect. F Struct. Biol. Commun. 2014, 70, 267-270. [CrossRef]

126. Del-Cid, A.; Ubilla, P.; Ravanal, M.C.; Medina, E.; Vaca, I.; Levicán, G.; Eyzaguirre, J.; Chávez, R. Cold-Active Xylanase Produced by Fungi Associated with Antarctic Marine Sponges. Appl. Biochem. Biotechnol. 2014, 172, 524-532. [CrossRef]

127. Zhang, L.L.; Tan, M.J.; Liu, G.L.; Chi, Z.; Wang, G.Y.; Chi, Z.M. Cloning and Characterization of an Inulinase Gene From the Marine Yeast Candida membranifaciens subsp. flavinogenie W14-3 and Its Expression in Saccharomyces sp. W0 for Ethanol Production Lin-Lin. Mol. Biotechnol. 2015, 57, 337-347. [CrossRef]

128. Doi, S.A.; Pinto, A.B.; Canali, M.C.; Polezel, D.R.; Merguizo Chinellato, R.A.; de Oliveira, A.J. Density and diversity of filamentous fungi in the water and sediment of Araca bay in Sao Sebastiao, Sao Paulo, Brazil. BIOTA Neotrop. 2018, 18, e20170416. [CrossRef]

129. Mäkelä, M.R.; Dilokpimol, A.; Koskela, S.M.; Kuuskeri, J.; de Vries, R.P.; Hildén, K. Characterization of a feruloyl esterase from Aspergillus terreus facilitates the division of fungal enzymes from Carbohydrate Esterase family 1 of the carbohydrate-active enzymes (CAZy) database. Microb. Biotechnol. 2018, 11, 869-880. [CrossRef]

130. Souza, P.M.; de Freitas, M.M.; Cardoso, S.L.; Pessoa, A.; Guerra, E.N.S.; Magalhães, P.O. Optimization and purification of L-asparaginase from fungi: A systematic review. Crit. Rev. Oncol. Hematol. 2017, 120, 194-202. [CrossRef]

131. Kebeish, R.M.; El-Sayed, A.S. Morphological and molecular characterization of L-methioninase producing Aspergillus species. Afr. J. Biotechnol. 2012, 11, 15280-15290.

132. Liu, Z.; Li, X.; Chi, Z.; Wang, L.; Li, J.; Wang, X. Cloning, characterization and expression of the extracellular lipase gene from Aureobasidium pullulans HN2-3 isolated from sea saltern. Antonie Van Leeuwenhoek 2008, 94, 245-255. [CrossRef]

133. Schreck, S.D.; Grunden, A.M. Biotechnological applications of halophilic lipases and thioesterases. Appl. Microbiol. Biotechnol. 2014, 98, 1011-1021. [CrossRef]

134. David, K. Factors influencing the activity of fungus lipase. J. Biol. Chem. 1935, 108, 421-430.

135. de Almeida, A.F.; Tauk-Tornisielo, S.M.; Carmona, E.C. Acid lipase from Candida viswanathii: Production, biochemical properties, and potential application. BioMed Res. Int. 2013, 2013, 1-10.

136. Verma, S.; Prasanna, R.; Saxena, J.; Sharma, V.; Nain, L. Deciphering the metabolic capabilities of a lipase producing Pseudomonas aeruginosa SL-72 strain. Folia Microbiol. (Praha) 2012, 57, 525-531. [CrossRef]

137. Guerrand, D. Lipases industrial applications: Focus on food and agroindustries. OCL 2017, 24, D403. [CrossRef]

138. Ferrer, M.; Golyshina, O.V.; Chernikova, T.N.; Khachane, A.N.; Martins, V.A.P.; Santos, D.; Yakimov, M.M.; Timmis, K.N.; Golyshin, P.N. Microbial Enzymes Mined from the Urania Deep-Sea Hypersaline Anoxic Basin. Chem. Biol. 2005, 12, 895-904. [CrossRef]

139. Kuddus, M. Cold-active enzymes in food biotechnology: An updated mini review. J. Appl. Biol. Biotechnol. 2018, 6, 58-63.

140. Linnakoski, R.; Reshamwala, D.; Veteli, P.; Cortina-Escribano, M.; Vanhanen, H.; Marjomäki, V. Antiviral Agents From Fungi: Diversity, Mechanisms and Potential Applications. Front. Microbiol. 2018, 9, 1-18. [CrossRef]

141. Gomes, N.; Lefranc, F.; Kijjoa, A.; Kiss, R. Can Some Marine-Derived Fungal Metabolites Become Actual Anticancer Agents? Mar. Drugs 2015, 13, 3950-3991. [CrossRef]

142. Silber, J.; Kramer, A.; Labes, A.; Tasdemir, D. From Discovery to Production: Biotechnology of Marine Fungi for the Production of New Antibiotics. Mar. Drugs 2016, 14, 137. [CrossRef]

143. Blunt, J.W.; Copp, B.R.; Keyzers, R.A.; Carroll, A.R.; Munro, M.M.H.G.; Prinsep, M.R. Marine natural products. Nat. Prod. Rep. 2018, 35, 8-53. [CrossRef] 
144. Wu, Z.; Wang, Y.; Liu, D.; Proksch, P.; Yu, S.; Lin, W. Antioxidative phenolic compounds from a marine-derived fungus Aspergillus versicolor. Tetrahedron 2016, 72, 50-57. [CrossRef]

145. Ventola, C.L. The Antibiotic Resistance: Part 1: Causes and treats. P T 2015, 40, 277-283.

146. Murugaiyan, K. Marine Fungal Diversity and Bioprospecting. In Springer Handbook of Marine Biotechnology; Kim, S.K., Ed.; Springer: Berlin, Germany, 2015; pp. 13-25.

147. Imhoff, J.F.; Labes, A.; Wiese, J. Bio-mining the microbial treasures of the ocean: New natural products. Biotechnol. Adv. 2011, 29, 468-482. [CrossRef]

148. Bhadury, P.; Mohammad, B.T.; Wright, P.C. The current status of natural products from marine fungi and their potential as anti-infective agents. J. Ind. Microbiol. Biotechnol. 2006, 33, 325-337. [CrossRef]

149. Saleem, M.; Ali, M.S.; Hussain, S.; Jabbar, A.; Ashraf, M.; Lee, Y.S. Marine natural products of fungal origin. Nat. Prod. Rep. 2007, 24, 1142-1152. [CrossRef]

150. Javed, F.; Qadir, M.I.; Janbaz, K.H.; Ali, M. Novel drugs from marine microorganisms. Crit. Rev. Microbiol. 2011, 37, 245-249. [CrossRef]

151. Sithranga Boopathy, N.; Kathiresan, K. Anticancer drugs from marine flora: An overview. J. Oncol. 2010, 2010. [CrossRef]

152. Demain, A.L.; Adrio, J.L. Contributions of Microorganisms to Industrial Biology. Mol. Biotechnol. 2008, 38, 41-55. [CrossRef]

153. Li, X.; Li, X.M.; Li, X.D.; Xu, G.M.; Liu, Y.; Wang, B.G. 20-Nor-isopimarane cycloethers from the deep-sea sediment-derived fungus: Aspergillus wentii SD-310. RSC Adv. 2016, 6, 75981-75987. [CrossRef]

154. Fredimoses, M.; Zhou, X.; Ai, W.; Tian, X.; Yang, B.; Lin, X.; Xian, J.Y.; Liu, Y. Westerdijkin A, a new hydroxyphenylacetic acid derivative from deep sea fungus Aspergillus westerdijkiae SCSIO 05233. Nat. Prod. Res. 2015, 29, 158-162. [CrossRef]

155. Shang, Z.; Li, X.; Meng, L.; Li, C.; Gao, S.; Huang, C.; Wang, B. Chemical profile of the secondary metabolites produced by a deep-sea sediment-derived fungus Penicillium commune SD-118. Chin. J. Oceanol. Limnol. 2012, 30, 305-314. [CrossRef]

156. Zhao, Y.; Chen, H.; Shang, Z.; Jiao, B.; Yuan, B.; Sun, W.; Wang, B.; Miao, M.; Huang, C. SD118-xanthocillin X (1), a novel marine agent extracted from Penicillium commune, induces autophagy through the inhibition of the MEK/ERK pathway. Mar. Drugs 2012, 10, 1345-1359. [CrossRef]

157. Xu, R.; Xu, G.M.; Li, X.M.; Li, C.S.; Wang, B.G. Characterization of a newly isolated marine fungus Aspergillus dimorphicus for optimized production of the anti-tumor agent wentilactones. Mar. Drugs 2015, 13, 7040-7054. [CrossRef]

158. Lv, C.; Hong, Y.; Miao, L.; Li, C.; Xu, G.; Wei, S.; Wang, B.; Huang, C.; Jiao, B. Wentilactone A as a novel potential antitumor agent induces apoptosis and G2/M arrest of human lung carcinoma cells, and is mediated by HRas-GTP accumulation to excessively activate the Ras/Raf/ERK/p53-p21 pathway. Cell Death Dis. 2013, 4, e952-e963. [CrossRef]

159. Zhang, Z.; Miao, L.; Lv, C.; Sun, H.; Wei, S.; Wang, B.; Huang, C.; Jiao, B. Wentilactone B induces G2/M phase arrest and apoptosis via the Ras/Raf/MAPK signaling pathway in human hepatoma SMMC-7721 cells. Cell Death Dis. 2013, 4, e657-e669. [CrossRef]

160. Renneberg, R. Biotech History: Yew trees, paclitaxel synthesis and fungi. Biotechnol. J. 2007, 2, 1207-1209. [CrossRef]

161. Stierle, A.; Strobel, G.; Stierle, D. Taxol and taxane production by Taxomyces andreanae, an endophytic fungus of Pacific yew. Science 1993, 260, 214-216. [CrossRef]

162. Zhou, X.; Zhu, H.; Liu, L.; Lin, J.; Tang, K. A review: Recent advances and future prospects of taxol-producing endophytic fungi. Appl. Microbiol. Biotechnol. 2010, 86, 1707-1717. [CrossRef]

163. Kusari, S.; Singh, S.; Jayabaskaran, C. Rethinking production of Taxol@(paclitaxel) using endophyte biotechnology. Trends Biotechnol. 2014, 32, 304-311. [CrossRef]

164. Qiao, W.; Ling, F.; Yu, L.; Huang, Y.; Wang, T. Enhancing taxol production in a novel endophytic fungus, Aspergillus aculeatinus Tax-6, isolated from Taxus chinensis var. mairei. Fungal Biol. 2017, 121, 1037-1044. [CrossRef]

165. Mulder, K.C.L.; Mulinari, F.; Franco, O.L.; Soares, M.S.F.; Magalhães, B.S.; Parachin, N.S. Lovastatin production: From molecular basis to industrial process optimization. Biotechnol. Adv. 2015, 33, 648-665. [CrossRef] 
166. Tobert, J.A. Lovastatin and beyond: The history of the HMG-COA reductase inhibitors. Nat. Rev. Drug Discov. 2003, 2, 517-526. [CrossRef]

167. Xiao, Z.; Lin, S.O.E.; Tan, C.; Lu, Y.; He, L.; Huang, X.; She, Z.; Xiao, Z.; Lin, S.O.E.; Tan, C.; et al. Asperlones $\mathrm{A}$ and B, dinaphthalenone derivatives from a mangrove endophytic fungus Aspergillus sp. 16-5C. Mar. Drugs 2015, 13, 366-378. [CrossRef]

168. Navarri, M.; Jégou, C.; Meslet-Cladière, L.; Brillet, B.; Barbier, G.; Burgaud, G.; Fleury, Y. Deep Subseafloor Fungi as an Untapped Reservoir of Amphipathic Antimicrobial Compounds. Mar. Drugs 2016, 14, 50. [CrossRef]

169. Zhao, H.G.; Wang, M.; Lin, Y.Y.; Zhou, S.L. Optimization of culture conditions for penicilazaphilone C production by a marine-derived fungus Penicillium sclerotiorum M-22. Lett. Appl. Microbiol. 2018, 66, 222-230. [CrossRef]

170. Zhou, S.L.; Wang, M.; Zhao, H.; Huang, Y.; Lin, Y.; Tan, G.; Chen, S. Penicilazaphilone C, a new antineoplastic and antibacterial azaphilone from the Marine Fungus Penicillium Sclerotiorum. Arch. Pharm. Res. 2016, 39, 1621-1627. [CrossRef]

171. Bigelis, R.; He, H.; Yang, H.Y.; Chang, L.P.; Greenstein, M. Production of fungal antibiotics using polymeric solid supports in solid-state and liquid fermentation. J. Ind. Microbiol. Biotechnol. 2006, 33, 815-826. [CrossRef]

172. Heinig, U.; Scholz, S.; Jennewein, S. Getting to the bottom of Taxol biosynthesis by fungi. Fungal Divers. 2013, 60, 161-170. [CrossRef]

173. Borthwick, A.D. 2,5-Diketopiperazines: Synthesis, Reactions, Medicinal Chemistry, and Bioactive Natural Products. Chem. Rev. 2012, 112, 3641-3716. [CrossRef]

174. Renshaw, J.C.; Robson, G.D.; Trinci, A.P.J.; Wiebe, M.G.; Livens, F.R.; Collison, D.; Taylor, R.J. Fungal siderophores: Structures, functions and applications. Mycol. Res. 2002, 106, 1123-1142. [CrossRef]

175. Uchida, R.; Nakajyo, K.; Kobayashi, K.; Ohshiro, T.; Terahara, T.; Imada, C.; Tomoda, H. 7-Chlorofolipastatin, an inhibitor of sterol O-acyltransferase, produced by marine-derived Aspergillus ungui NKH-007. J. Antibiot. (Tokyo) 2016, 69, 647-651. [CrossRef]

176. Zhang, X.Y.; Zhang, Y.; Xu, X.Y.; Qi, S.H. Diverse deep-sea fungi from the south china sea and their antimicrobial activity. Curr. Microbiol. 2013, 67, 525-530. [CrossRef]

177. Rodríguez-Martín, A.; Acosta, R.; Liddell, S.; Núñez, F.; Benito, M.J.; Asensio, M.A. Characterization of the novel antifungal protein PgAFP and the encoding gene of Penicillium chrysogenum. Peptides 2010, 31, 541-547. [CrossRef]

178. Visamsetti, A.; Ramachandran, S.S.; Kandasamy, D. Penicillium chrysogenum DSOA associated with marine sponge (Tedania anhelans) exhibit antimycobacterial activity. Microbiol. Res. 2016, 185, 55-60. [CrossRef]

179. De la Torre, P.; Meyer, D.K.; Reboli, A.C. Anidulafungin: A novel echinocandin for candida infections. Future Microbiol. 2008, 3, 593-601. [CrossRef]

180. Lee, C.; Sohn, J.H.; Jang, J.-H.; Ahn, J.S.; Oh, H.; Baltrusaitis, J.; Hwang, I.H.; Gloer, J.B. Cycloexpansamines A and B: Spiroindolinone alkaloids from a marine isolate of Penicillium sp. (SF-5292). J. Antibiot. (Tokyo) 2015, 68, 715-718. [CrossRef]

181. Bringmann, G.; Gulder, T.A.M.; Lang, G.; Schmitt, S.; Stöhr, R.; Wiese, J.; Nagel, K.; Imhoff, J.F. Large-scale biotechnological production of the antileukemic marine natural product sorbicillactone A. Mar. Drugs 2007, 5, 23-30. [CrossRef]

182. Guzmán-Chávez, F.; Salo, O.; Nygård, Y.; Lankhorst, P.P.; Bovenberg, R.A.L.; Driessen, A.J.M. Mechanism and regulation of sorbicillin biosynthesis by Penicillium chrysogenum. Microb. Biotechnol. 2017, 10, 958-968. [CrossRef]

183. Bu, Y.Y.; Yamazaki, H.; Takahashi, O.; Kirikoshi, R.; Ukai, K.; Namikoshi, M. Penicyrones A and B, an epimeric pair of $\alpha$-pyrone-type polyketides produced by the marine-derived Penicillium sp. J. Antibiot. (Tokyo) 2016, 69, 57-61. [CrossRef]

184. Wu, Z.H.; Liu, D.; Xu, Y.; Chen, J.L.; Lin, W.H. Antioxidant xanthones and anthraquinones isolated from a marine-derived fungus Aspergillus versicolor. Chin. J. Nat. Med. 2018, 16, 219-224. [CrossRef]

185. Kawahara, T.; Takagi, M.; Shin-ya, K. Three new depsipeptides, JBIR-113, JBIR-114 and JBIR-115, isolated from a marine sponge-derived Penicillium sp. fS36. J. Antibiot. (Tokyo) 2012, 65, 147-150. [CrossRef]

186. Fenical, W.; Jensen, P.R.; Cheng, X.C. Avrainvillamide, a Cytotoxic Marine Natural Product, and the Derivatives Thereof. U.S. Patent US6066635, 23 May 2000. 
187. Kanoh, K.; Kohno, S.; Asari, T.; Harada, T.; Katada, J.; Muramatsu, M.; Kawashima, H.; Sekiya, H.; Uno, I. (-)-Phenylahistin: A new mammalian cell cycle inhibitor produced by Aspergillus ustus. Bioorganic Med. Chem. Lett. 1997, 7, 2847-2852. [CrossRef]

188. Li, Y.; Ye, D.; Shao, Z.; Cui, C.; Che, Y. A sterol and spiroditerpenoids from a Penicillium sp. isolated from a deep sea sediment sample. Mar. Drugs 2012, 10, 497-508. [CrossRef]

189. Dong, Y.; Cui, C.B.; Li, C.W.; Hua, W.; Wu, C.J.; Zhu, T.J.; Gu, Q.Q. Activation of dormant secondary metabolite production by introducing neomycin resistance into the deep-sea fungus, Aspergillus versicolor ZBY-3. Mar. Drugs 2014, 12, 4326-4352. [CrossRef]

190. Saraiva, N.N.; Rodrigues, B.S.F.; Jimenez, P.C.; Guimarães, L.A.; Torres, M.C.M.; Rodrigues-Filho, E.; Pfenning, L.H.; Abreu, L.M.; Mafezoli, J.; De Mattos, M.C.; et al. Cytotoxic compounds from the marine-derived fungus Aspergillus sp. recovered from the sediments of the Brazilian coast. Nat. Prod. Res. 2015, 29, 1545-1550. [CrossRef]

191. Li, C.S.; Li, X.M.; Gao, S.S.; Lu, Y.H.; Wang, B.G. Cytotoxic anthranilic acid derivatives from deep sea sediment-derived fungus Penicillium paneum SD-44. Mar. Drugs 2013, 11, 3068-3076. [CrossRef] [PubMed]

192. Zhuravleva, O.I.; Afiyatullov, S.S.; Vishchuk, O.S.; Denisenko, V.A.; Slinkina, N.N.; Smetanina, O.F. Decumbenone $\mathrm{C}$, a new cytotoxic decaline derivative from the marine fungus Aspergillus sulphureus KMM 4640. Arch. Pharm. Res. 2012, 35, 1757-1762. [CrossRef] [PubMed]

193. Huang, Z.; Yang, J.; Cai, X.; She, Z.; Lin, Y. A new furanocoumarin from the mangrove endophytic fungus Penicillium sp. (ZH16). Nat. Prod. Res. 2012, 26, 1291-1295. [CrossRef] [PubMed]

194. Wang, J.; Wang, Q.L.; Nong, X.H.; Zhang, X.Y.; Xu, X.Y.; Qi, S.H.; Wang, Y.F. Oxalicumone A, a new dihydrothiophene-condensed sulfur chromone induces apoptosis in leukemia cells through endoplasmic reticulum stress pathway. Eur. J. Pharmacol. 2016, 783, 47-55. [CrossRef]

195. Wu, G.; Lin, A.; Gu, Q.; Zhu, T.; Li, D. Four new chloro-eremophilane sesquiterpenes from an antarctic deep-sea derived fungus, Penicillium sp. PR19N-1. Mar. Drugs 2013, 11, 1399-1408. [CrossRef] [PubMed]

196. Wang, C.C.C.; Chiang, Y.M.; Praseuth, M.B.; Kuo, P.L.; Liang, H.L.; Hsu, Y.L. Asperfuranone from Aspergillus nidulans inhibits proliferation of human non-small cell lung cancer A549 cells via blocking cell cycle progression and inducing apoptosis. Basic Clin. Pharmacol. Toxicol. 2010, 107, 583-589. [CrossRef]

197. Balibar, C.J.; Howard-Jones, A.R.; Walsh, C.T. Terrequinone A biosynthesis through L-tryptophan oxidation, dimerization and bisprenylation. Nat. Chem. Biol. 2007, 3, 584-592. [CrossRef]

198. Gamal-Eldeen, A.M.; Abdel-Lateff, A.; Okino, T. Modulation of carcinogen metabolizing enzymes by chromanone $\mathrm{A}$; a new chromone derivative from algicolous marine fungus Penicillium sp. Environ. Toxicol. Pharmacol. 2009, 28, 317-322. [CrossRef]

199. Zhen, X.; Gong, T.; Wen, Y.-H.; Yan, D.-J.; Chen, J.-J.; Zhu, P. Chrysoxanthones A-C, three new Xanthone-Chromanone heterdimers from sponge-associated Penicillium chrysogenum HLS111 treated with histone deacetylase inhibitor. Mar. Drugs 2018, 16, 357. [CrossRef]

200. Gerhards, N.; Neubauer, L.; Tudzynski, P.; Li, S.M. Biosynthetic pathways of ergot alkaloids. Toxins (Basel). 2014, 6, 3281-3295. [CrossRef]

201. Pócsi, I.; Jeney, V.; Kertai, P.; Pócsi, I.; Emri, T.; Gyémánt, G.; Fésüs, L.; Balla, J.; Balla, G. Fungal siderophores function as protective agents of LDL oxidation and are promising anti-atherosclerotic metabolites in functional food. Mol. Nutr. Food Res. 2008, 52, 1434-1447. [CrossRef] [PubMed]

202. Van Den Berg, M.A.; Albang, R.; Albermann, K.; Badger, J.H.; Daran, J.M.; Driessen, A.J.; Garcia-Estrada, C.; Fedorova, N.D.; Harris, D.M.; Heijne, W.H.M.; et al. Genome sequencing and analysis of the filamentous fungus Penicillium chrysogenum. Nat. Biotechnol. 2008, 26, 1161-1168. [CrossRef] [PubMed]

203. Nutzmann, H.W.; Reyes-Dominguez, Y.; Scherlach, K.; Schroeckh, V.; Horn, F.; Gacek, A.; Schumann, J.; Hertweck, C.; Strauss, J.; Brakhage, A.A. Bacteria-induced natural product formation in the fungus Aspergillus nidulans requires Saga/Ada-mediated histone acetylation. Proc. Natl. Acad. Sci. USA 2011, 108, 14282-14287. [CrossRef] [PubMed]

204. Garrigues, S.; Gandía, M.; Castillo, L.; Coca, M.; Marx, F.; Marcos, J.F.; Manzanares, P. Three antifungal proteins from Penicillium expansum: Different patterns of production and antifungal activity. Front. Microbiol. 2018, 9, 1-15. [CrossRef] [PubMed]

205. Zhang, Y.; LI, X.-M.; Wang, B.-G. Anthraquinone Derivatives Produced by Marine-Derived Fungus Aspergillus versicolor EN-7. Biosci. Biotechnol. Biochem. 2012, 76, 1774-1776. [CrossRef] [PubMed] 
206. Patel, R.N. Biocatalysis for synthesis for chiral pharmaceutical intermediates. In Biocatalysis in the Pharmaceutical and Biotechnology Industries; CRC Press: Boca Raton, FA, USA, 2006; pp. 105-151.

207. Endo, A.; Kuroda, M.; Tsujita, Y. ML-236A, ML-236B, and ML-236C, new inhibitors of cholesterogensis produced by Penicillium citrinum. J. Antibiot. (Tokyo) 1976, 29, 1346-1348. [CrossRef] [PubMed]

208. Feingold, K.R.; Grunfeld, C. Cholesterol-Lowering Drugs; MDText.com, Inc.: South Dartmouth, MA, USA, 1999; Volume 8.

209. Alberts, A.W.; Chen, J.; Kuron, G.; Hunt, V.; Huff, J.; Hoffman, C.; Rothrock, J.; Lopez, M.; Joshua, H.; Harris, E.; et al. Mevinolin: A highly potent competitive inhibitor of hydroxymethylglutaryl-coenzyme A reductase and a cholesterol-lowering agent. Proc. Natl. Acad. Sci. USA 1980, 77, 3957-3961. [CrossRef] [PubMed]

210. Pejin, B.; Karaman, M. Antitumor Natural Products of Marine-Derived Fungi. In Fungal Metabolites; Springer: Cham, Switzerland, 2017; pp. 1-28.

211. Akcil, A.; Erust, C.; Ozdemiroglu, S.; Fonti, V.; Beolchini, F. A review of approaches and techniques used in aquatic contaminated sediments: Metal removal and stabilization by chemical and biotechnological processes. J. Clean. Prod. 2015, 86, 24-36. [CrossRef]

212. Prasad, R. Mycoremediation and Environmental Sustainability; Springer: Berlin, Germany, 2018.

213. Deshmukh, R.; Khardenavis, A.A.; Purohit, H.J. Diverse Metabolic Capacities of Fungi for Bioremediation. Indian J. Microbiol. 2016, 56, 247-264. [CrossRef]

214. Gillespie, I.M.M.; Philp, J.C. Bioremediation, an environmental remediation technology for the bioeconomy. Trends Biotechnol. 2013, 31, 329-332. [CrossRef]

215. Mishra, A.; Malik, A. Recent Advances in Microbial Metal Bioaccumulation. Crit. Rev. Environ. Sci. Technol. 2013, 43, 1162-1222. [CrossRef]

216. Cerniglia, C.E. Fungal metabolism of polycyclic aromatic hydrocarbons: Past, present and future applications in bioremediation. J. Ind. Microbiol. Biotechnol. 1997, 19, 324-333. [CrossRef] [PubMed]

217. Marco-Urrea, E.; García-Romera, I.; Aranda, E. Potential of non-ligninolytic fungi in bioremediation of chlorinated and polycyclic aromatic hydrocarbons. New Biotechnol. 2015, 32, 620-628. [CrossRef] [PubMed]

218. Harms, H.; Schlosser, D.; Wick, L.Y. Untapped potential: Exploiting fungi in bioremediation of hazardous chemicals. Nat. Rev. Microbiol. 2011, 9, 177-192. [CrossRef] [PubMed]

219. Passarini, M.R.Z.; Rodrigues, M.V.N.; da Silva, M.; Sette, L.D. Marine-derived filamentous fungi and their potential application for polycyclic aromatic hydrocarbon bioremediation. Mar. Pollut. Bull. 2011, 62, 364-370. [CrossRef] [PubMed]

220. Haritash, A.K.; Kaushik, C.P. Biodegradation aspects of Polycyclic Aromatic Hydrocarbons (PAHs): A review. J. Hazard. Mater. 2009, 169, 1-15. [CrossRef]

221. Ciullini, I.; Tilli, S.; Scozzafava, A.; Briganti, F. Fungal laccase, cellobiose dehydrogenase, and chemical mediators: Combined actions for the decolorization of different classes of textile dyes. Bioresour. Technol. 2008, 99, 7003-7010. [CrossRef]

222. Wang, M.X.; Zhang, Q.L.; Yao, S.J. A novel biosorbent formed of marine-derived Penicillium janthinellum mycelial pellets for removing dyes from dye-containing wastewater. Chem. Eng. J. 2015, 259, 837-844. [CrossRef]

223. Asses, N.; Ayed, L.; Hkiri, N.; Hamdi, M. Congo Red Decolorization and Detoxification by Aspergillus niger: Removal Mechanisms and Dye Degradation Pathway. BioMed Res. Int. 2018, 2018, 1-9. [CrossRef]

224. Garza, M.T.G.; Perez, D.B.; Rodriguez, A.V.; Garcia-Gutierrez, D.I.; Zarate, X.; Cardenas, M.E.C.; Urraca-Botello, L.I.; Lopez-Chuken, U.J.; Trevino-Torres, A.L.; De Cerino-Córdoba, F.J.; et al. Metal-induced production of a novel bioadsorbent exopolysaccharide in a native Rhodotorula mucilaginosa from the mexican northeastern region. PLoS ONE 2016, 11, e0148430.

225. Arun, A.; Raja, P.P.; Arthi, R.; Ananthi, M.; Kumar, K.S.; Eyini, M. Polycyclic Aromatic Hydrocarbons (PAHs) Biodegradation by Basidiomycetes Fungi, Pseudomonas Isolate, and Their Cocultures: Comparative In Vivo and In Silico Approach. Appl. Biochem. Biotechnol. 2008, 151, 132-142. [CrossRef] [PubMed]

226. Whiteley, C.G.; Lee, D.J. Enzyme technology and biological remediation. Enzyme Microb. Technol. 2006, 38, 291-316. [CrossRef]

227. Karigar, C.S.; Rao, S.S. Role of microbial enzymes in the bioremediation of pollutants: A review. Enzyme Res. 2011, 2011, 1-12. [CrossRef] [PubMed] 
228. Zehra, A.; Dubey, M.K.; Meena, M.; Aamir, M.; Patel, C.B.; Upadhyay, R.S. Role of Penicillium Species in Bioremediation Processes. In New and Future Developments in Microbial Biotechnology and Bioengineering; Gupta, V.K., Rodriguez Couto, S., Eds.; Elsevier: Amsterdam, The Netherlands, 2018; pp. 247-260.

229. Vieira, G.A.L.; Magrini, M.J.; Bonugli-Santos, R.C.; Rodrigues, M.V.N.; Sette, L.D. Polycyclic aromatic hydrocarbons degradation by marine-derived basidiomycetes: Optimization of the degradation process. Brazilian J. Microbiol. 2018, 49, 749-756. [CrossRef] [PubMed]

230. Singh, B.K.; Walker, A. Microbial degradation of organophosphorus compounds. FEMS Microbiol. Rev. 2006, 30, 428-471. [CrossRef] [PubMed]

231. Adeleye, A.O.; Nkereuwem, M.E.; Omokhudu, G.I.; Amoo, A.O.; Shiaka, G.P.; Yerima, M.B. Effect of microorganisms in the bioremediation of spent engine oil and petroleum related environmental pollution. J. Appl. Sci. Environ. Manag. 2018, 22, 157. [CrossRef]

232. Boguslawska-Was, E.; Dąbrowski, W. The seasonal variability of yeasts and yeast-like organisms in water and bottom sediment of the Szczecin Lagoon. Int. J. Hyg. Environ. Health 2001, 203, 451-458. [CrossRef]

233. Wu, Y.R.; He, T.T.; Lun, J.S.; Maskaoui, K.; Huang, T.W.; Hu, Z. Removal of Benzo[a]pyrene by a fungus Aspergillus sp. BAP14. World J. Microbiol. Biotechnol. 2009, 25, 1395-1401. [CrossRef]

234. Vala, A.K. On the Extreme Tolerance and Removal of Arsenic by a Facultative Marine Fungus Aspergillus sydowii; Gautam, A., Pathak, C., Eds.; Daya Publishing House: New Delhi, India, 2017.

235. Vala, A.K.; Sutariya, V. Trivalent arsenic tolerance and accumulation in two facultative marine fungi. Jundishapur J. Microbiol. 2012, 5, 542-545. [CrossRef]

236. Vala, A.K.; Anand, N.; Bhatt, P.N.; Joshi, H.V. Tolerance and accumulation of hexavalent chromium by two seaweed associated aspergilli. Mar. Pollut. Bull. 2004, 48, 983-985. [CrossRef]

237. Khambhaty, Y.; Mody, K.; Basha, S.; Jha, B. Biosorption of $\mathrm{Cr}(\mathrm{VI})$ onto marine Aspergillus niger: Experimental studies and pseudo-second order kinetics. World J. Microbiol. Biotechnol. 2009, 25, 1413-1421. [CrossRef]

238. Coreno-Alonso, A.; Solé, A.; Diestra, E.; Esteve, I.; Gutiérrez-Corona, J.F.; Reyna Lopez, G.E.; Fernanández, F.J.; Tomasini, A. Mechanisms of interaction of chromium with Aspergillus niger var tubingensis strain Ed8. Bioresour. Technol. 2014, 158, 188-192. [CrossRef] [PubMed]

(C) 2019 by the authors. Licensee MDPI, Basel, Switzerland. This article is an open access article distributed under the terms and conditions of the Creative Commons Attribution (CC BY) license (http://creativecommons.org/licenses/by/4.0/). 